\title{
An Overview of Literature Topics Related to Current Concepts, Methods, Tools, and Applications for Cumulative Risk Assessment (2007-2016)
}

\author{
Mary A. Fox ${ }^{1}$, L. Elizabeth Brewer ${ }^{2}$ and Lawrence Martin ${ }^{3, *}$ \\ 1 Department of Health Policy and Management, Bloomberg School of Public Health, Johns Hopkins \\ University, Baltimore, MD 21205, USA; mfox9@jhu.edu \\ 2 Office of the Science Advisor, U.S. Environmental Protection Agency, Oak Ridge Institute for Science and \\ Education (ORISE), Washington, DC 20004, USA; brewer.beth@epa.gov \\ 3 Office of the Science Advisor, U.S. Environmental Protection Agency, Washington, DC 20004, USA \\ * Correspondence: martin.lawrence@epa.gov; Tel.: +1-202-564-6497
}

Academic Editor: Paul B. Tchounwou

Received: 5 December 2016; Accepted: 21 March 2017; Published: 7 April 2017

\begin{abstract}
Cumulative risk assessments (CRAs) address combined risks from exposures to multiple chemical and nonchemical stressors and may focus on vulnerable communities or populations. Significant contributions have been made to the development of concepts, methods, and applications for CRA over the past decade. Work in both human health and ecological cumulative risk has advanced in two different contexts. The first context is the effects of chemical mixtures that share common modes of action, or that cause common adverse outcomes. In this context two primary models are used for predicting mixture effects, dose addition or response addition. The second context is evaluating the combined effects of chemical and nonchemical (e.g., radiation, biological, nutritional, economic, psychological, habitat alteration, land-use change, global climate change, and natural disasters) stressors. CRA can be adapted to address risk in many contexts, and this adaptability is reflected in the range in disciplinary perspectives in the published literature. This article presents the results of a literature search and discusses a range of selected work with the intention to give a broad overview of relevant topics and provide a starting point for researchers interested in CRA applications.
\end{abstract}

Keywords: cumulative risk assessment; nonchemical stressor; chemical mixture; vulnerable populations; community health; environmental justice; ecological health

\section{Introduction and Background}

\subsection{Objectives of This Manuscript}

This paper is organized and written in a manner that is intended to function as a reference guide for overarching concepts, commonly used techniques, and innovative methods for cumulative risk assessment (CRA). The human health, ecological health, and ecosystem services results sections introduce and briefly highlight papers that are presented in the tables in the Supplementary Materials. This manuscript presents work from each of these subject areas in an effort to address recommendations to develop more integrative approaches to assessing cumulative risks. Although the focus is on human health, papers from the ecological literature provide complementary or potentially adaptable methods and approaches. The discussion section presents a synthesis of these papers.

Some sections further highlight certain articles out of those presented in the tables. It is not the intent of the authors to comment on data quality or to provide a ranking of the presented studies, but to direct attention to papers that represent a certain subject or that present essential concepts and methods. There are numerous studies from many different disciplines that could provide useful 
methods to CRA, but because CRAs can be stressor-oriented, effects-based, or community or population specific, it is impossible to predict what studies might be relevant. Therefore, papers are highlighted because they focus on providing information that is particularly important to developing new and innovative methods for CRA, or have broad applicability to many aspects of CRA. Because CRA can be designed to focus analysis on a diverse range of issues, and draws from a wide range of information, the selection of literature in this review is intended to provide a perspective and starting point for interested researchers.

\subsection{What Is Cumulative Risk Assessment (CRA)?}

In guidance documents for CRA [1,2], the U.S. Environmental Protection Agency (EPA or the Agency) defines a CRA as an analysis, characterization and possible quantification of the combined risks to health or the environment from multiple agents or stressors. The National Research Council's (NRC) Committee on Improving Risk Analysis Approaches Used by the EPA proposed CRA be defined as evaluating an array of stressors (chemical and nonchemical) to characterize quantitatively - to the extent possible-human health or ecological effects, taking account of such factors as vulnerability and background exposures [3]. The concept of cumulative effects has roots in the Council on Environmental Quality (CEQ) regulations implementing the National Environmental Policy Act (NEPA) of 1969 (Pub. L. No. 91-190), which included some principles of cumulative effects analysis for environmental impact assessments under NEPA [4]. Some of the key developments in cumulative risk concepts over time are provided in Supplementary Materials (Table S1).

\subsection{Literature Selection and Synthesis Approach}

In developing this report, PubMed, Web of Science, and Scopus were comprehensively searched on two occasions; first in 2011, and again in 2016 to update the original document. The databases were searched for the terms "CRA", "integrated assessment", "psychosocial stress", "chemical mixtures", and "ecological risk" from January 2007 to October 2011. They were searched again in May 2016 for the same terms listed above with the addition of the terms "disproportionate risk" and "ecosystem services". Search terms were selected based on consultation with EPA Risk Assessment Forum staff.

Search terms were chosen to explore a defined set of topics based on consultation with EPA staff. For this reason, a systematic review approach for this inquiry was not employed. Literature selection methods were instead modified to examine identified topics, and to capture as much relevant research as possible. Traditional methods for formulating systematic review questions would be more applicable for a CRA if tailored for a specific population, set of stressors, and health outcome. The type of information that could potentially be useful for future CRAs in specific populations or among multiple stressors is difficult to predict and should be tailored to fit a prescribed purpose. The search terms selected for this review are indicative of the evolving nature of CRA (e.g., the search term "ecosystem services" was added in the update to the original review).

The selected literature is presented in three sections-human health, ecological health, and ecosystem services. The ecosystem services section presents literature that bridges the gap between human and ecological health. The papers reviewed and presented in the ecosystem services section were published between 2011 and 2016, as this was a new term added later in the review.

Included in the references are two relevant studies [5,6] submitted through a Federal Register notice requesting information and citations on methods for CRA (Docket ID No. EPA-HQ-ORD-2013-0292). The combined database search resulted in 1752 references from early 2007 through mid-2016.

The articles cited in this review were filtered from the 1752 references. Article titles were reviewed to identify an underlying order to topics in the reference list. Papers are organized according to these topic areas. Questions were designed to capture relevant articles using NRC and EPA-developed CRA definitions and concepts (see Section 1.2) [2,3]. Abstracts were reviewed and filtered using these selection questions: 
- Does the article specifically address cumulative risk assessment?

- Does the article specifically address cumulative risk, cumulative effects, combined exposures, multiple routes of exposure, additivity, synergistic or antagonistic effects?

- Does the article address community health or environmental justice?

- Does the article roughly fit into a risk assessment step (Problem Formulation, Dose Response, Exposure Assessment, Hazard Identification, Risk Analysis, Risk Characterization) or a combination of steps?

- Is the article representative of a discipline (e.g., social epidemiology, ecotoxicology) and does it also address its method's applicability to cumulative or multiple risks, exposures or effects?

- Does the article address common difficulties in evaluating cumulative risks (e.g., approaches for estimating joint action in chemical mixtures, measuring allostatic load (AL), impacts of nonchemical stressors)?

- Does the article address susceptibility or vulnerability?

- Does the article present novel methods for incorporating nonchemical stressors with the evaluation of chemical risks?

- Does the article address any of the recommendations of the NRC [3,7] reports?

The resulting full text articles were then examined for inclusion in this review (see Figure 1 for process overview). Other papers cited in this review are for supplying necessary background information or for further discussion.

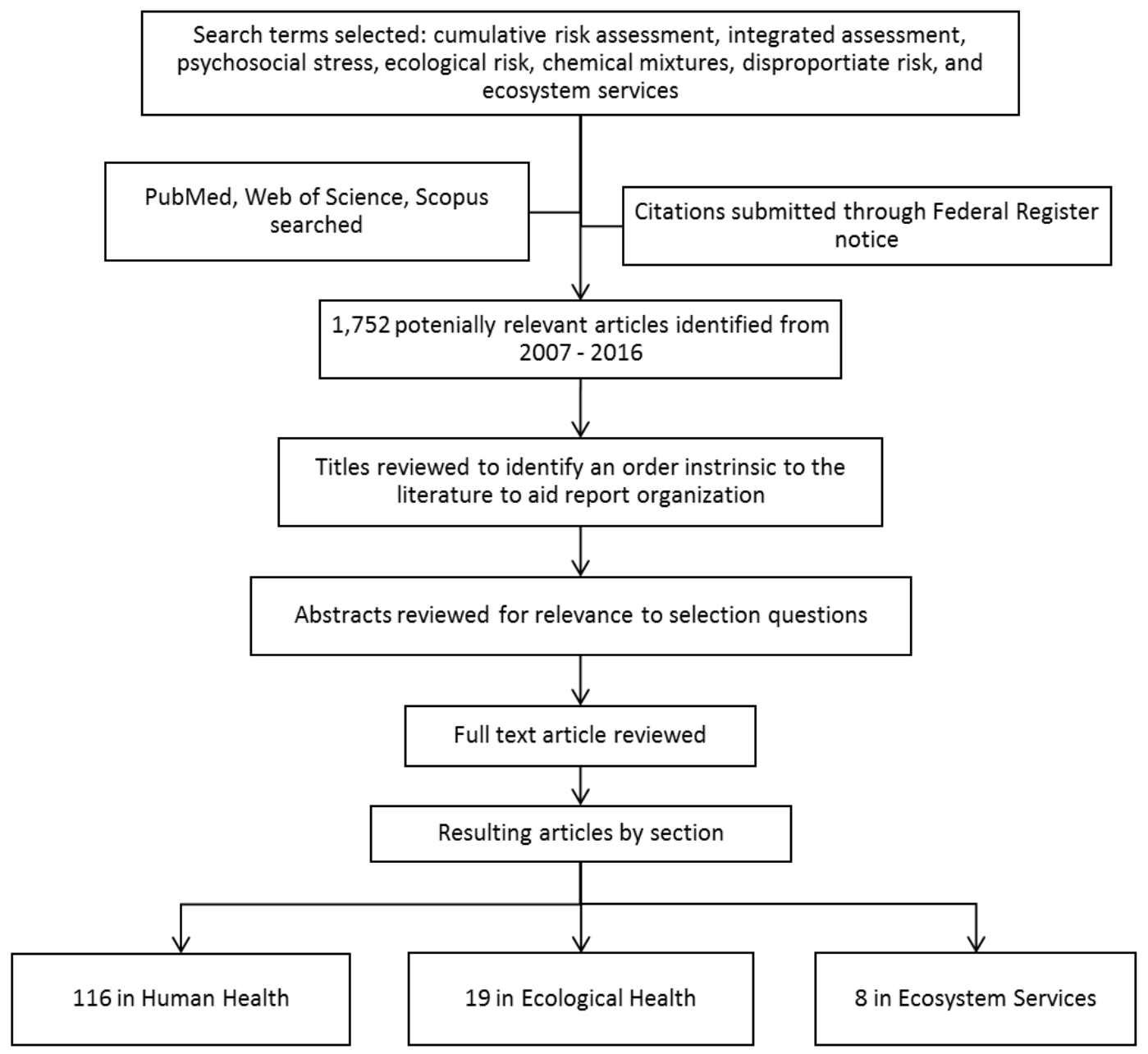

Figure 1. Flow chart of literature selection process. 


\section{Results-Human Health}

Key features of cumulative risk and human health papers presented in the tables in the Supplementary Materials and highlighted in this section are summarized in Table 1 below.

\subsection{Review Articles}

\subsubsection{Nonchemical Stressors and Cumulative Risk Assessment: An Overview}

A review by Lewis et al. [8] provides an overview of important CRA concepts and summarizes investigations of the impact of social stressors on health. The investigations are drawn primarily from the air pollution epidemiology literature, although a few studies of blood and bone lead are included. The epidemiological research Lewis et al. gathered addressed social stressors as effect modifiers in the relationships between air pollutant exposures and health effects ranging from asthma to mortality. In the subset of studies of blood and bone lead, the outcomes were neurological, including IQ decrement, mental development scores and other cognitive measures. The underlying studies were not re-evaluated for this review, and specific aspects of study design and implementation or variations in how stressors are defined may explain some of the heterogeneity in the findings as reported by Lewis et al. [8]. Despite concluding that the evidence they reviewed offered mixed results regarding the impact of nonchemical stressors, Lewis and co-authors were optimistic about the potential to apply epidemiological research methods to quantify the effects of nonchemical stressors. Recommendations offered by Lewis et al. for advancing CRA included a few topics that apply to risk assessment in general, such as better quantification of exposure and focused efforts to apply epidemiological findings in risk assessments. The other critical needs for cumulative risk research and practice identified were:

- Continued attention to extrapolation from animal studies (i.e., How well does stress induced in animals relate to psychosocial stress in humans?).

- Identification of biomarkers that may provide a means to integrate effects of chemical and nonchemical stressors (see [9]).

- Measures or metrics of nonchemical stressors that facilitate dose-response assessment.

- Methods to quantify interactions between chemical and nonchemical stressors and describe differences in dose-response curves.

- Epidemiological evaluations that explore the relative contributions of chemical and nonchemical stressors and how such findings relate to dose-response.

- Methods and metrics for cumulative risk characterization.

In the context of this literature review, Lewis et al. made a unique contribution by keying their analysis to the risk assessment "steps" (e.g., hazard identification, exposure assessment). As a caution, however, the review is not systematic and is not intended to be "an exhaustive analysis" [8] (p. 2022). Another issue to note, observed by Lewis et al. [8] and in the many studies reviewed below, is that there are many ways to represent or measure social stress, ranging from area-level social stress indicators developed from census information to individual self-reports and survey instruments, indicators of social class, and a neighborhood-level psychosocial hazard index. 
Table 1. Summary of highlighted papers—cumulative risk and human health.

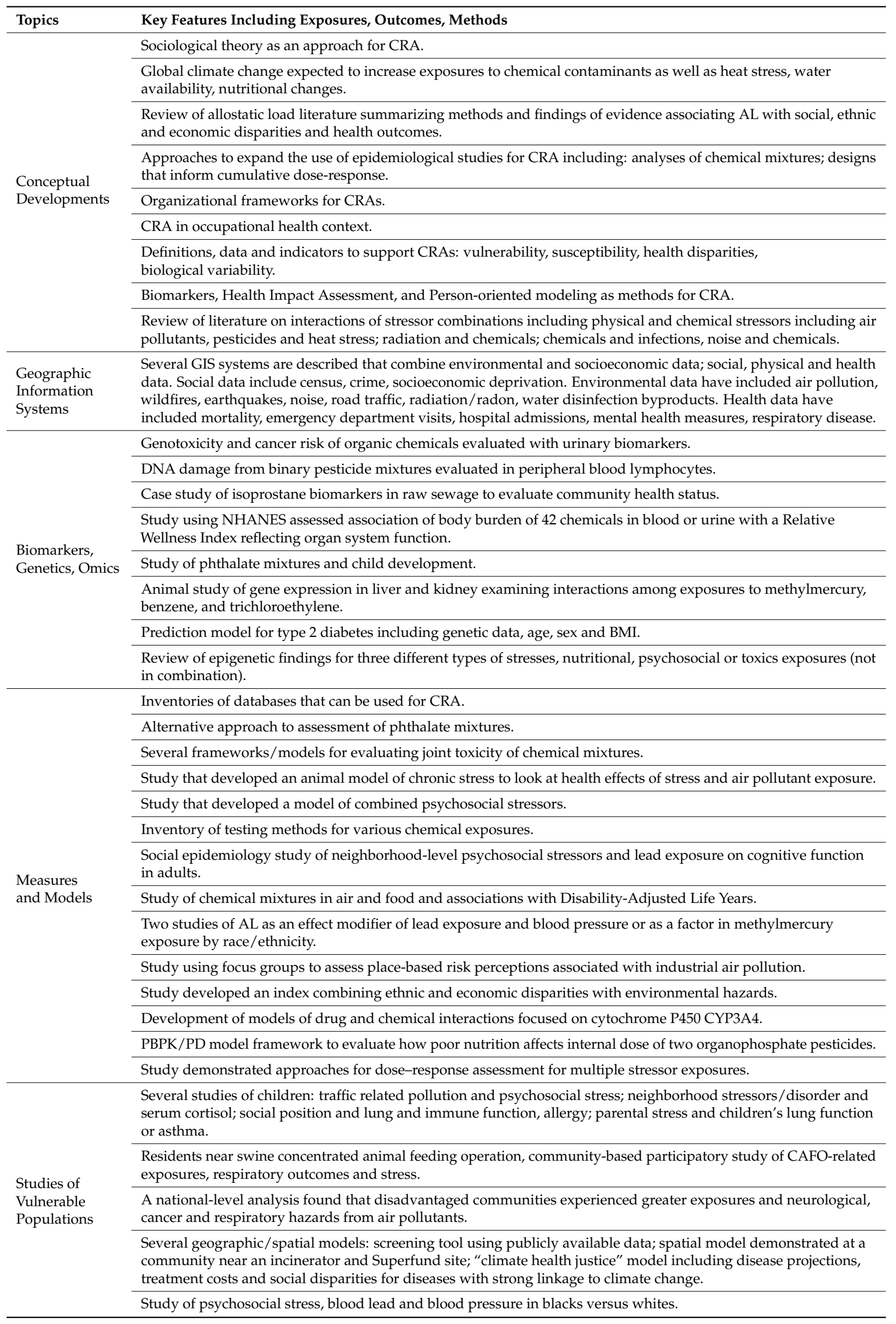




\subsubsection{An Update on Phthalates Toxicology}

In their update, Rider et al. [10] documented then-recent work on phthalates and other anti-androgens providing an update on the science reviewed by the NRC Committee on the Health Effects of Phthalates [7]. Rider et al. reviewed findings of studies that evaluated various types of mixtures of male reproductive toxicants. The various mixtures tested represented different mechanisms of toxicity (e.g., androgen receptor agonist, enzyme inhibition) as well as diverse toxicity pathways (androgen- vs. aryl hydrocarbon-receptor signaling). The effects observed in these studies were well-predicted by dose-additivity and exceeded predictions made on the basis of response-additivity. The authors concluded:

“...our results indicate that compounds that act by disparate mechanisms of toxicity to disrupt the dynamic interactions among the interconnected signaling pathways in differentiating tissues produce cumulative dose-additive effects, regardless of the mechanism or mode of action of the individual mixture component" [10] (p. 443).

Rider et al. [10] present evidence from their studies of phthalates and other anti-androgens and argue for expanding the organizing principle for CRAs from "common mechanism of toxicity" to include "common adverse outcome" as well, as recommended by the NRC Committee on the Health Effects of Phthalates [7].

\subsection{Conceptual Developments}

Types of papers categorized as conceptual developments in CRA are summarized in Table 1 with additional details in Table S2. These include thought pieces on cumulative risk from different disciplinary perspectives, e.g., anthropology [11], sociology [12], and health geography [13]; frameworks and approaches for conducting or designing CRAs [5,14-20], biomonitoring approaches [9], and epidemiological approaches [21]; and definitions and discussion of important concepts, including interindividual variability [22], AL [23], and psychosocial stressors [24].

\subsection{Cumulative Risk Methods and Applications for Human Health}

The types of methods and applications of cumulative risk represented in the literature review fall into four main categories: geographic information systems (GIS) (see Table S3); emerging work in biomarkers, genetics and "omics" (see Table S4); varied modeling approaches (see Table S5); and continued application and some refinements of CRA for pesticides. The latter work is summarized in the following Section 2.3.1 (the papers are not included in the tables).

\subsubsection{Applications and Developments in Cumulative Exposure and Risk Assessment of} Chemical Mixtures

\section{Pesticides}

Methods used by EPA's Office of Pesticide Programs have been adopted by others to evaluate exposure and risk resulting from exposure to pesticides with a common mechanism of action and their residues in diet or particular foods [25-27]. Bosgra et al. [28] reported on development of an isobologram approach to predict effects from chemical mixtures, but later reported a preference for a biological/physiological model [29-31]. Muller et al. [32] used relative potency factors to evaluate exposures and risks from anti-androgenic pesticides in food. Abdo et al. [33] used an in vitro model to evaluate hazard, mode of action, and population variability in response to pesticide mixtures. Jensen et al. [34] used the hazard index approach to assess chronic cumulative dietary exposure to pesticide mixtures. Kennedy et al. [35] demonstrated probabilistic approaches for uncertainty analysis for pesticides, including a discussion of probability from Bayesian and frequentist perspectives. Moretto [36] recommended in vitro testing and PBPK modeling to refine pesticide groupings. 
The European Food Safety Authority (EFSA) released a scientific opinion on assessing the cumulative risk of pesticide mixtures in food in support of the "common adverse outcome" approach recommended in the NRC's phthalates report [7]. The opinion recommended dose addition (DA) as a conservative default method for the assessment of pesticides with a dissimilar mode of action (MOA), given that they produce common adverse outcomes in the same target organs or systems [6].

\section{Other Chemical Mixtures}

Dewalque et al. [37], Hartmann et al. [38], and Wang et al. [39] provided examples of current CRAs of phthalate exposure in geographically distinct populations; Dewalque et al. [37] and Hartmann et al. [38] addressed phthalate mixtures in the Belgian and Austrian general populations respectively, while Wang et al. [39] focused on children in three areas in China, finding that children living in manufacturing intensive areas are at a highest risk of phthalate exposure. Pelallo-Martinez et al. [40], also focusing on children in industrial areas, used urinary biomarkers to assess exposure to a mixture of lead, benzene, toluene, and polyaromatic hydrocarbons (PAHs), and find that variation in the levels of PAHs in the mixture modifies the genotoxic and hematological effects of exposure. Maffini and Neltner [41] explored deficits in traditional risk assessment methods, identified over 300 food additives that may cause adverse effects in the developing brain, and urged more focus on cumulative biological effects. Henn et al. [42] focused on children's health outcomes in a review of recent epidemiological literature examining chemical mixtures.

The following papers explored various aspects of exposure to chemical mixtures and demonstrated crossover in techniques among disciplines, conceptual advances, and new assessment methods:

- Lee and Jacobs [43] discussed glutathione depletion and mitochondrial dysfunction resulting from chronic exposure to persistent organic pollutants (POPs), and how physical stressors and behavioral factors can be counteractive measures mitigating the impacts of POP exposure.

- Orton et al. [44] demonstrated combination in vitro effects of mixtures containing a large variety of current use androgen receptor antagonistic chemicals.

- Ge et al. [45] characterized the impacts of exposure to metal mixtures in vitro using a systems biology approach integrating proteomics, bioinformatics, statistics, and computational toxicology.

- Hadrup [46] suggested that chemicals should be prioritized based on potency and risk of exposure, and an overall estimate of chemical mixture effects on all targets would be a more effective strategy for risk assessment than dose addition and grouping by target organ.

Three scientific committees of the European Commission's Directorate General for Health and Consumers published recommendations on the evaluation of chemical mixtures in 2011, "Toxicity and Assessment of Chemical Mixtures". The report recommended DA when MOAs are similar and independent action (IA) when chemicals act through dissimilar modes of action. DA is also recommended as a default method in the absence of MOA information. The report's discussion and recommendations include consideration of mixture evaluation in both human and ecological assessment.

\subsubsection{Highlights from the Geographic Information Systems Literature}

Studies utilizing GIS and spatial analysis contribute to epidemiologic evidence for geographic influences on multistressor exposures and health outcomes. In Table S3, papers to note in the literature on GIS are Basara and Yuan [47] and Briggs et al. [48]. Basara and Yuan [47] described a GIS that combines social, physical/chemical and health outcome data sets; it is an example of a data system developed from surveillance data. The work of Briggs et al. [48] takes the next step and employs a GIS database that evaluated environmental inequities in England. In addition, Salinas et al. [49] and Huang and London [50] developed methods to assess the impact of multiple environmental stressors on community health using spatial analysis. Although listed among the important contributions to the 
Vulnerable Populations literature in Table S6, the work of Alexeeff et al. [51] and McDonald et al. [52] should also be noted as a significant addition to the GIS literature. The work of Shmool et al. [53] looked at psychosocial stressors and air pollution in New York City using GIS-based analysis.

\subsubsection{Highlights from the Biomarker, Genetic and "Omics" Literature}

Several interesting papers were found in the emerging area of biological methods for cumulative risk, and are presented in Table S3. Of note are the biomarkers examples [54-57] from human studies and the toxicological work of Hendriksen et al. [58]. Two papers were found that discussed the "how-to" of gene-environment studies and epigenetics that will be informative for designing cumulative risk studies using these approaches [59,60]. Innovative papers from Daughton [61] and Gennings et al. [62] explored the potential of biomarker research from a systems biology perspective. Bonefeld-Jorgensen et al. [63] found ex vivo integrated biomarkers of POP mixtures have the potential to clarify pathways from emissions to health risks. Mentioned in Conceptual Developments Section 2.2 above, Smith et al. [20] described how the exposome can be used to assess cumulative risks, and take steps forward in characterizing a variety of current research efforts, including the "Public Health Exposome" [64], that have potential to advance CRA.

Although CRA studies with biomonitoring data continue to develop, this area is challenging. There are many scientific and technical considerations such as:

- Timing of exposure and sampling-it may be difficult to obtain samples of compounds with short half-lives in the body.

- Difficulty in determining the source, pathway, or duration of exposure from biomarkers.

- Characterization of biomarkers. It is unclear how well-characterized the biomarkers are with respect to their links to exposure, susceptibility or health effects [9].

Despite these challenges, Smith et al. [20] demonstrated that exposomic analysis has contributed to advancements in the characterization of biomarkers, and elucidation of biological responses at the individual and population level to chemical and nonchemical stressors originating in different types of environments (i.e., natural, built, social, and political).

\subsubsection{Measures and Models}

The papers categorized as relating to "measures and models" are summarized in Table 1 with additional detail in Table S5. Contributions to measures and models for CRA include inventories of publicly available measurement instruments and databases [65-67]; development of indices of social and psychosocial factors [68,69]; studies of AL [70,71]; an animal model of chronic social stress [72]; evidence synthesis methods for epidemiological data [73]; and dose-response studies of chemical and non-chemical stressors [74-76].

\subsection{Cumulative Risk Examples-Vulnerable Populations}

Schwartz et al. [77] explored sources of vulnerability and susceptibility including age, socioeconomic position, and psychosocial stress, and provide empirical examples of how these factors modify risk from exposure to lead and air pollution. Table S6 provides a summary of studies of vulnerability in key populations and lifestages of concern including children and environmental justice communities. Theall et al. [78] and Dulin-Keita et al. [79] evaluated adverse physiological responses to neighborhood-level stressors in children. Other examples of children's cumulative risk are several studies of air pollutants, stress and childhood asthma or lung function; Pearlman [80] reviewed this topic area.

Among the studies of air pollutants, stress and childhood asthma or lung function presented in Table S6, three reports show that presence of home-related stress increases vulnerability to exacerbation of asthma or reduced lung function [81-83]. The work of Hoffmann et al. [84] reported complex results, finding that although socially disadvantaged children experienced higher exposures to total 
suspended particulates (TSP) and tobacco smoke and had more unfavorable living conditions, they were less likely to report respiratory diseases but more likely to have abnormal lung function in clinical testing. Explanations offered for the complex findings were selection or reporting bias and biologic interactions [84]. Additional results on childhood asthma and environmental exposures from the Asthma Coalition on Community, Environment, and Social Stress Project will be forthcoming based on the work of Wright et al. [85]. Erickson and Arbour [86] reviewed studies examining socioeconomic risk factors as effect modifiers (rather than confounders) of the effect of exposure to air pollution on pregnancy outcomes, suggesting that socioeconomic stressors and air pollutants share similar etiologic pathways and recommending targeted intervention strategies at multiple levels of organization.

Examples of analysis that examined environmental justice communities include one near a Florida Superfund site [87] and the work of Wing and colleagues who evaluated the health impacts on neighbors of industrial hog farms in North Carolina. They are exemplary for the design, implementation, and outcomes of community-based participatory research [88-91].

Alexeeff et al. [51] developed and demonstrated a screening methodology for identifying potential environmental justice communities. Further characterizing relationships under the environmental justice framework, Schule and Bolte [92] systematically reviewed epidemiological studies of neighborhood socioeconomic position and objective measures of the built environment on individual health outcomes using multilevel models.

It should be noted that clear cut definitions of vulnerability and susceptibility are not part of the studies in this review and therefore the authors do not attempt to define the terms and may use the terms interchangeably.

\section{Results-Ecological Health}

Key features of cumulative risk, ecological health, and ecosystem services papers presented in the tables in the Supplementary Materials and highlighted in this section are summarized in Table 2 below.

Table 2. Summary of highlighted papers—cumulative risk and ecology or ecosystems.

\begin{tabular}{|c|c|}
\hline Topics & Key Features Including Exposures, Outcomes, Methods \\
\hline \multirow{3}{*}{ Conceptual Developments } & Review of ecotoxicological literature on chemical, biological and physical stressors. \\
\hline & Study of life-course and sequencing of exposure in crustacean. \\
\hline & Review of selected case studies examining climate change, toxicant exposure and ecosystem health. \\
\hline \multirow{4}{*}{ Measures and Models } & Study of biomarkers of exposure in fish to inform follow-up studies on health effects. \\
\hline & $\begin{array}{l}\text { Studies of complex mixtures (insecticides and/or herbicides or organic compounds) examining CA and IA } \\
\text { dose-response models (crustacean, bacteria). }\end{array}$ \\
\hline & Study of pesticide and heat stress on salmon. \\
\hline & Study of mercury and other chemical and physical stressors in rivers (abiotic and biotic endpoints). \\
\hline \multirow{5}{*}{$\begin{array}{l}\text { Studies of Ecological Areas } \\
\text { or Populations }\end{array}$} & $\begin{array}{l}\text { Application of Bayesian methods to model of different types of socioeconomic development on a } \\
\text { large ecosystem. }\end{array}$ \\
\hline & Experimental model of chronic stress in fish with exposure to fasting or heat. \\
\hline & Study of zooplankton chemical and physical stressors. \\
\hline & $\begin{array}{l}\text { Review of ecological studies (aquatic and terrestrial plants and animals) that assessed dose-response models } \\
\text { (CA, IA) of combinations of radiation and other stressors. }\end{array}$ \\
\hline & Experiment on bees assessing infection and exposure to pesticides. \\
\hline \multirow{3}{*}{$\begin{array}{l}\text { Conceptual Developments } \\
\text { (Ecosystem Services) }\end{array}$} & Integration of ecosystem perspective into ecological risk assessment framework. \\
\hline & Linking human health to ecosystem services. \\
\hline & Adaptation of DPSEEA model; defining "ecological public health". \\
\hline \multirow{4}{*}{$\begin{array}{l}\text { Measures and Models } \\
\text { (Ecosystem Services) }\end{array}$} & $\begin{array}{l}\text { EPA Eco-Health Relationship Browser summarizes literature on positive effects of ecosystem services on } \\
\text { human health. }\end{array}$ \\
\hline & GIS tool to assess community access to ecosystem services. \\
\hline & Framework to identify data indicating ecosystem impact on human well-being. \\
\hline & Indices of human well-being and dependence on ecosystem services. \\
\hline
\end{tabular}




\subsection{Conceptual Developments}

The field of ecological risk assessment has a strong experimental component, in contrast to human cumulative risk, which must rely on observational studies or toxicological research that require extrapolation between species. Papers representing conceptual developments in ecological CRA are presented in Table S7. Holmstrup et al. [93] summarized some of the large body of work on ecological risks of combinations of chemical and nonchemical stressors (although in somewhat simple combinations). An important concept that has not been studied extensively is the sequence and timing of exposures [93-96]. Holmstrup et al. [93] pointed to the need to prioritize the types of stressor combinations likely to be most potent to maximize gains from future research. Lokke [94] summarized some of the highlights of the NoMiracle project that were reported in a special issue of Science of the Total Environment, including databases and experimental test systems. Among conclusions of the NoMiracle work is a need to focus on the receptor rather than particular stressors, echoing the calls for effects-based assessments for human cumulative risk $[7,14]$. In a discussion of climate change in ecotoxicology, Moe et al. [96] highlighted the importance of studying the effects of current and future climate stress on population vulnerability to toxicants.

\subsection{Methods and Applications}

Developments in methods for ecological risk (see Table S8) include applications of "omics" (e.g., [97]), fuzzy set theory for dose-response [98] and work on the most efficient experimental designs for mixture research [99]. Al-Salhi et al. [100], Garcia-Reyero et al. [101], and Baylay et al. [102] demonstrated more "omics" applications.

One theme in ecological health literature was the continued exploration of concentration addition versus independent action as the most appropriate models for assessing joint effects; this topic is addressed separately in Section 3.2.

Testing Models of Combined Effects-Continuing Exploration of Concentration Addition (CA) or Independent Action (IA) to Predict Joint Effects

Several papers captured the continuing debate about the most appropriate use of the CA or IA models in predicting effects of mixtures of stressors in ecological populations. Coors and De Meester [103] found that IA was useful in a study looking at predation threat, parasitism and pesticide exposure in Daphnia magna. Ferreira et al. [104] reported limitations of the models (i.e., circumstances in which one or both models failed to accurately predict effects of multiple stressors). Ferreira et al. [104] also suggests the need for data on toxicological mechanisms to further advance understanding of the effects of complex mixtures. The work of Cedergreen et al. [105] is summarized in more detail below because it reports on the evaluation of a large database of ecotoxicological studies. This evaluation echoed the findings of other authors but went further to offer general guidance on applying CA and IA for complex multi-stressor assessments.

Cedergreen et al. [105] investigated the argument that IA is the most theoretically correct reference model for predicting joint effects of chemical mixtures with different molecular targets (i.e., MOAs). Their study employed 158 existing data sets representing 98 different mixtures, mostly of pesticides and drugs, in one or more of seven common ecotoxicological test systems. The analysis showed that only 20 percent of the mixtures were adequately predicted by IA and only 10 percent by CA. Approximately 50 percent of mixtures could not be described correctly by either model. Although they could not recommend either model on the basis of accuracy, the authors made three recommendations based on the findings and the populations assessed in the data sets examined:

- CA was recommended as a conservative or protective approach in cumulative assessments for individuals.

- IA was recommended as quantitatively most conservative in assessments addressing multiple species or ecosystem level assessments. 
- The selection of the model for a joint effects assessment should consider the purpose and context of the assessment and not just the MOAs for the chemicals of concern.

After evaluating the utility of CA and IA alongside species sensitivity distribution curves for assessing chemical mixture risks in ecosystems, Gregorio et al. [106] concluded that CA can lead to underestimations and IA can lead to under- or overestimations of mixture effects. In a review of pesticide mixtures in aquatic systems, CA is found to be a reasonably accurate and conservative approach for effect estimation [107]. This finding is in agreement with Cedergreen and coworkers' [105] first recommendation listed above. Using mathematical models, Kamo and Yokomizo [108] investigated effects in chemical mixtures and found CA to be accurate only at low concentrations. At higher concentrations, mixture effects can be predicted by CA when MOAs are exactly the same, whereas mixtures characterized by similarities in the MOAs generally produce nonlinear effects.

Backhaus and Faust [109] proposed a tiered approach for mixtures risk assessment, where applying CA is suggested as a conservative and precautious first-tier approach regardless of the MOAs in the mixture. Consideration of IA in the second tier happens only if the calculated risk quotient in the first tier indicates potential risk, or if CA produces an overestimation of risk based on expert opinion. MOA analysis is a last resort if there are considerable differences in effect estimates derived from CA and IA.

A review of mixture toxicity assessments from the last 20 years from Altenburger et al. [110] pointed out that recent mixture studies employing CA or IA are still ambiguous. To reduce ambiguity, the authors suggest more researchers study the utility of CA and IA extended to the molecular level using transcriptomic, proteomic, and metabolomics approaches. Studying CA and IA at the molecular level will aid in better understanding of MOAs, provide better information for interspecies extrapolations, and improve extrapolations from short-term studies to long-term exposure scenarios [110].

\subsection{Cumulative Risk Examples-Ecological Health}

Langmead et al. [111] reported a cumulative risk study of the influence of country-level societal decision making on ecological resources with a case study of the Black Sea region. The framework for the study was the Drivers-Pressures-States-Impact-Response (DPSIR) conceptual model [111]. This work seems to be a unique contribution in terms of its scope and approach in characterizing impacts of very large social development processes and in the use of Bayesian belief networks as a tool for combining information. Landis et al. [112] also used a Bayesian network relative risk model to assess the effects of mercury contamination along with chemical and physical stressors on multiple endpoints in a Virginia river. They suggest that risk management plans considering all stressors are more effective than plans focusing on regulatory criteria for a single chemical (mercury). The study also demonstrates the Bayesian network as an effective tool for adaptive management plans, capable of updating risk measures based on proposed interventions.

The ecotoxicology literature has many examples of chemical and physical stressor combinations, such as pesticide and temperature change or low oxygen conditions [93,113]. Of note in Table S9 are studies reflecting a current trend of exploring the joint effects of climate change and toxicant exposure [114,115]. The work of Vidau et al. [116] provides an example of a chemical and biological stressor combination.

\section{Results-Ecosystem Services}

\subsection{Background}

The Millennium Ecosystem Assessment (MEA) [117] evaluated links between ecosystem degradation and human well-being and prompted efforts to develop conceptual frameworks for and quantify the effects of ecosystem services on human health and well-being. Because the health and 
extent of the natural environment affects the quality and abundance of ecosystem services, and human health is affected by the products of natural systems, ecosystem services constitute a causal link between ecological and human health risk assessment. As CRA seeks to evaluate combined risks to multiple stressors, with community health being a major driving force behind its development, enhancing the flow of information between two traditionally disparate disciplines is vital to fully understanding cumulative risks in defined populations. Therefore, this section highlights recent articles that help elucidate the role ecosystem services play in the connection between ecological and human health risk assessment.

An update to EPA's Generic Ecological Assessment Endpoints for Ecological Risk Assessment [118] includes generic ecosystem service (EPA/100/F15/005). An accompanying technical background paper described the science supporting the linkage between ecological structure and function, and ecological services to society (EPA/100/F15/004). The background paper is summarized by Munns et al. [119].

\subsection{Conceptual Developments}

Myers et al. [120] characterized the current research on health impacts of ecosystem services and described its limitations. Reis et al. [121] and De Laender and Janssen [122] discussed methods for integrating ecosystem services into existing risk assessment paradigms. These three studies are summarized in Table S10.

\subsection{Methods and Applications}

Articles in Table S11 explored the development of indices for quantifying ecosystem impacts on human health. Of note are the works of Ringold et al. [123] and Norman et al. [124], who demonstrated novel methods that enhance collaboration across multiple disciplines to evaluate health and well-being.

\section{Promising Data Sources for Cumulative Risk Studies}

The data and research generated from the National Children's Study's pilot effort, the Vanguard Study, could be a fruitful resource for secondary analyses of cumulative risk and children's health; these data are archived and are available upon request [125]. Kim et al. [126] described the Mothers and Children's Environmental Health (MOCEH) study in Korea, a prospective cohort of pregnant women and their children who will be followed to age 5 . The most recent analysis to come out of the MOCEH study is from Bhang et al. [127] and examined relationships between maternal stress and infant developmental outcomes adjusting for prenatal heavy metal exposure.

In addition to those publications that indexed available databases applicable for CRA [65-67], recent efforts have resulted in a public health exposome database and a toxic exposome database [64,128]. The exposome databases house an impressive breadth of information and could be useful for toxicologists, epidemiologists, biochemists, and omics-based disciplines interested in utilizing those resources for CRA applications.

\section{Discussion: Summary of the State of the Practice of CRA}

\subsection{Limitations}

Our review captured ten years of literature focused on the risk analysis process but did not address cumulative risk management or decision making. This review summarizes this broad literature and is intended to introduce scientists and risk assessors to the variety of approaches that could be applied to understand cumulative exposures and risks. Readers seeking additional details in the tables in the Supplementary Materials may find that some papers appear connected, i.e., a research need described in one paper is addressed in another. This is not surprising since our search covered a ten-year period but we did not attempt to track or link papers in this way. Further, we did not undertake quality evaluation of the literature identified. This field of work is relatively new and includes many 
disciplines; there is no "standard" cumulative risk assessment and there are no "standard" methods. It may be possible to conduct evaluation in the future as the field develops; with experience it may be found that particular approaches and methods are shown to be valid and reliable for certain types of cumulative risk analyses.

The studies included have addressed chemical mixtures and different combinations of stressors but many cumulative risk questions have yet to be tackled and our understanding of cumulative risks is limited. The search terms did not include particular stressors or some important issues such as exposures to pharmaceuticals through environmental media, or the impacts of genetically modified organisms on ecosystem services or our food system. Here, again, it is important to note that the studies included in this review are representative of conceptual or methodological advances and it is not the intent of the authors to evaluate the weight of evidence for the impacts of any particular stressor. It is also clear that, given the complexity of cumulative exposures, no matter what method(s) are applied uncertainty will remain. The core principles and practices of risk assessment including evaluation, quantification (when possible) and discussion of uncertainty and the values of prevention and harm reduction will continue to be essential for environmental health protection efforts addressing cumulative exposures and risks.

\subsection{Summary and Highlights of Literature Reviewed}

The pioneering work of Fox et al. [129] was an early application of cumulative risk methods to understand community health and investigate environmental justice concerns. The key features of this work were the assessment of a large mixture of Hazardous Air Pollutants (HAPs) and incorporating multiple health effects per HAP in a community-level study. Fox et al. looked at the correlations and associations between total, cardiovascular and respiratory mortality and HAP health risks at the census tract level in south and southwest Philadelphia. The investigators included some simple stratified analyses by white and nonwhite populations and used per capita income and percent nonwhite population as control variables in regression analyses. They used a GIS to produce descriptive maps of HAP risk scores. The main finding of the work was that increased HAP risk scores were associated with increased total and respiratory mortality [129].

The literature gathered for this review covered 2007 to 2016. Cumulative risk work in this time period includes significant advances in methods, research and thinking about complex environmental exposures and risks beyond that represented by Fox et al. [129]. Perhaps most important is the availability of measures of nonchemical stressors beyond census data (e.g., ways to represent the social context, instruments to assess chronic life stress, animal models of stress). GIS applications also are much more sophisticated, including the development of databases with chemical and nonchemical exposure information as well as health outcomes $[47,48]$. There now are examples in the literature of powerful statistical methods well suited for cumulative risk problems, including multilevel modeling that allows the incorporation of individual- and group- or place-level data. There are also several examples of Bayesian methods and applications of fuzzy set theory.

The role of CA and IA models in predicting combined effects from chemical mixtures is uncertain $[106,110,130]$, although several articles agree that CA is best reserved for conservative effect estimation $[6,107,109]$ or estimation at low concentrations [108]. Studies in both human health and ecological health tackled the alterations in chemical risks that could occur from global climate change [96,114,131]. McEwen and Tucker [132] recognized the need for advancing research on the biological pathways through which stress affects health and modifies the effects of toxicant exposure. Dulin-Keita et al. [79] and Zota et al. [71] provided insights into these pathways in their research.

There was a noticeable trend over time towards a more holistic approach to assessing cumulative risks as recommended by Cutchin [13]. Hennig et al. [133] suggested diet become a part of the risk assessment paradigm as a critical modulator between environmental pollutants and health status. GIS applications from Salinas et al. [49] and Huang and London [50] used indices that included health status, economic, environmental and social datasets. Gennings et al. [62] extended the systems 
biology approach to human well-being using biomarkers and a Relative Wellness Index (RWI). AL as an intermediary element in health outcomes took on a prominent role in more recent studies of cumulative risk. A number of review articles pointed to a widening evidence base for cumulative risks, and investigation of links between social and environmental stressors [16,17,43,86,92].

Approaches linking ecological and human health risk assessments through ecosystems services also are promising. There is a large and growing evidence base for the influence of ecosystem services on human health [117] and existing research provides methods for quantifying this impact $[123,134]$.

\section{An Essential Reading List}

Table S12 highlights the papers from this review that capture essential concepts, methods and new directions in research approaches and findings. By reading these papers, scientists new to the CRA field would find the conceptual bases and examples of studies that could fuel design and implementation of further and much-needed research.

\subsection{Types of CRA Studies Represented in Literature Reviewed (Stressor- or Effects-Based Assessments)}

Menzie et al. [14] described two broad types of risk assessments, stressor- and effects-based assessments. Stressor-based assessments start with consideration of the stressors of concern, generally chemicals but increasingly nonchemical stressors as well. Effects-based assessments begin with identification of health effects of concern (e.g., high rates of cancer or childhood asthma). The majority of research identified in this review was stressor-based (A particular investigation may be initiated from concerns of certain health effects but eventually be presented as a stressor-based assessment in the peer-reviewed literature, perhaps to better conform to expectations of editors or peer-reviewers in environmental science fields). The standard risk assessment paradigm, with its focus on chemical stressors of regulatory concern, is likely a major contributor to the paucity of effects-based assessments.

The Menzie et al. paper [14] and the NRC report on Cumulative Risks of Phthalates: The Tasks Ahead [7] may help researchers to see the value of, and way to execute effects-based assessments. Menzie et al. [14] described a systematic approach, including a step-by-step process for effects-based assessments. The main recommendation of the phthalates report, that common adverse outcomes should become a focus of CRA efforts, also is a call for effects-based assessments.

\subsection{Discussion of Literature Reviewed Following Recommendations from the National Research Council}

The NRC's Committee on the Health Risks of Phthalates recommended common adverse outcomes as the organizing principle for CRAs (not the more limited common mechanism approach). The committee recommended that cumulative assessments of common adverse outcomes take into consideration multiple types of stressors that act via multiple dissimilar mechanisms.

Research on phthalates and other anti-androgens continues to be the primary example of risk assessment work addressing "common adverse outcomes" [10]. The literature included papers describing exposures to varied stressors and mechanisms (e.g., [135]). From the ecological risk assessment literature, Vidau et al. [116] and Langmead et al. [111] are relevant examples of studies of stressors that act via dissimilar mechanisms of action on outcomes of concern.

The main recommendations of the Science and Decisions report [3] for CRA were the following:

- Consider methods and approaches from ecological risk assessment and social epidemiology.

- Increase the role of biomonitoring, epidemiology and surveillance data in CRA.

- Develop simpler analytic tools.

- Consider and apply data on vulnerability and susceptibility.

All of these points are addressed in the papers reviewed in the Conceptual Developments Sections 2.2, 3.1 and 4.2, and to some extent in the research and examples reviewed, although much more can and will be done to develop these recommendations for CRAs. Many studies explored new 
approaches to using biomonitoring, epidemiology (and social epidemiology), and surveillance data (e.g., $[61,62,71,74,136])$. Among contributions from social epidemiology are indices of social context (e.g., neighborhood psychosocial hazards [68]) and studies that examine stressors such as parental or household stress on children's health [81,82]. Many epidemiological studies were captured in this review, and the majority of these looked at respiratory outcomes associated with air pollution exposures acting in concert with nonchemical stressors (e.g., social context, area-level SES), as mentioned above (see, for example, $[8,73,85,86,88])$.

In terms of simpler analytic tools, EPA has invested in databases and GISs to facilitate CRAs, as reflected in papers by Barzyk et al. [66], Zartarian and Schultz [137], MacDonell et al. [67] and Zartarian et al. [138]. The GIS applications summarized above provide new ways to assess chemical, physical and social exposures and sometimes health outcomes. Many of these GIS applications also use surveillance data for CRAs. Susceptibility and vulnerability were considered by Alexeeff et al. [51], Hicken et al. [139], Young et al. [140], Norman et al. [124], in CRAs of chemical mixture exposure in children [39,40], and in a comprehensive review by Zeise et al. [22].

There was a substantial amount of cross-over between disciplines represented in the reviewed studies. For example, a social epidemiological study by Theall et al. [78] considered vulnerability using biomarker data. Papers presented in Section 4, Ecosystem Services, indicated work is under way to combine the efforts of ecological and human health risk assessment.

\subsection{Discussion of Reviewed Literature in the Context of the Risk Assessment "Steps"}

Considering the literature reviewed as it relates to the "steps" of traditional risk assessment, problem formulation and exposure assessment were represented best. The numerous papers summarized in Conceptual Developments supported problem formulation by defining important concepts and frameworks for describing multiple contributors to health risk and suggested ways to operationalize them with data.

The many GIS articles supported efforts at exposure assessment by combining data on chemical and nonchemical stressors so high-combination exposure sites can be identified. Alexeeff et al. [51], Salinas et al. [49], Huang and London [50], and Norman et al. [124] developed GIS methods for screening vulnerable communities, and these methods could be considered useful for hazard identification. Research results reporting dose-response relationships are represented (e.g., [71,72]), although some methods may need to be developed to allow incorporation of unconventional results (e.g., [62]) into risk assessments. Methods for synthesizing dose-response estimates reported for multiple stressors across multiple studies are described in Levy et al. [73], and greatly contributes to arguably one of the most difficult areas of CRA. For risk characterization, Landis et al. [112], for example, has demonstrated that Bayesian techniques can be successfully used improve characterization of uncertainty and provide more information relevant to decision-making.

\subsection{Progress Report: What Is the State of the Practice?}

\subsubsection{Weight of Evidence on Chemical Mixtures and Chemical and Nonchemical Stressors and} Health Impacts

There is ample evidence from both human and ecological risk assessment fields that multiple-chemical and mixed-stressor exposures increase risks to health. On the ecological health side, for which the experimental evidence is strong, additive models routinely are applied and thought to provide conservative risk estimates [105,107]. The review of ecotoxicological studies by Holmstrup et al. [93] reported many examples of synergism and few examples of antagonism. Novel "omics" approaches in the ecotoxicological literature were used as a guide to clarifying the roles of CA and IA in effects at the molecular level, and provided further evidence of ecological health impacts. 


\subsubsection{Exposures and Outcomes Examined So Far}

Work on the effects of psychosocial stress of lead exposure and blood pressure [71,139], neighborhood disorder on AL in children [98,99], and reviews of the evidence of interactions between chemical and nonchemical stressors in both ecological and human health were captured in this literature review.

The majority of work on, or related to, human health that has addressed both chemical and nonchemical stressors has focused on air pollution exposure and mortality as well as respiratory outcomes (see [8]). Some articles evaluated diet and nutrition as an important intermediate in exposure-disease relationships [5,74,133]. A few studies have examined lead exposure, nonchemical stressors and neurological outcomes (also reviewed in [8]). Notable work with chemical mixtures includes the following:

- Hendriksen et al. [58] looked at mixtures of methyl mercury, benzene and trichloroethylene on liver and kidney effects in rats.

- Navas-Acien et al. [141] looked at joint exposure to lead and cadmium and kidney function in a population study.

- Al Zabadi et al. [54] used urinary biomarkers to assess exposure and genotoxicity to some polyaromatic hydrocarbons and volatile organics in an occupational study.

- Zota et al. [57] looked at exposures to multiple polybrominated diphenyl ethers and measures of thyroid function in pregnant women.

- Pelallo-Martinez et al. [40] assessed genotoxic and hematological effects of exposure to chemical mixtures in children living in industrial areas using urinary biomarkers.

Phthalates and other anti-androgen mixtures research is directed at male reproductive development and neurological development [10,56]. Studies of pesticide mixtures included organophosphates and carbamates (acetylcholinesterase (AChE) inhibition) and anti-androgenic pesticides (see $[25,26]$ ). There were several chemical mixture CRAs conducted since 2014 (see Other Chemical Mixtures in Section 2.3.1), indicating that the evidence base for evaluation of risk in this area is robust and growing.

The body of work on combined exposures and ecological health risks was not exhaustively reviewed here. A few papers documented studies of chemical mixtures from small two-chemical combinations to up to 15 chemicals, including pesticides and persistent organics. According to Holmstrup et al. [93], the majority of cumulative ecological risk studies of chemical and nonchemical stressors have looked at only two factors. Some studies demonstrated methods and models new to ecological health, for instance, a fish model of chronic stress or metabolomics approaches to mixture identification and investigation of effects [100,102,142]. A recent ecological risk study demonstrates integration of a combination of 12 chemical and nonchemical stressor using Bayesian modeling techniques [112]. Ecological CRA outcomes cover a full spectrum from individual and population outcomes (e.g., growth, survival, and population abundance) to the "omics" (genomics, transcriptomics, etc.).

\subsubsection{Promising Complementary Approaches to CRA}

In addition to the new directions for CRA identified by the recent NRC panels, two other promising approaches were identified in this review: health geography and HIA. Cutchin [13] suggests that a "new health geography" can complement approaches to social epidemiology that may tend toward a reductionist risk factor approach. The concepts of health geography contribute to a better understanding of places and offer ways to understand the dynamics of social, physical and chemical exposures [13].

Morello-Frosch et al. [143] suggest that HIA may be a good tool to address CRA questions. HIA features strong stakeholder involvement, and health is conceptualized across many determinants, including but not limited to environmental chemicals [144,145]. 
The adverse outcome pathway (AOP) conceptual framework maps connections between stressors, molecular initiating events, and adverse health outcomes [146]. The AOP framework is a multidisciplinary approach to evaluating risks and incorporates information from computational toxicology, in vitro studies, and animal studies. It provides a visual representation of toxicological mechanisms or modes of action linked to health effects of interest in a population. The AOP framework may be useful in CRAs to map pathways from stressors to outcomes and investigate levels of uncertainty associated with data that indicates linkages between important variables. Mapping AOPs can provide a way to evaluate multiple stressor-effect pathways, and it is envisioned that as AOPs and networks of AOPs are constructed and gathered into a knowledge database, human health and ecological risk assessment will benefit from its predictive capabilities [147].

Decision analysis is an additional resource that can help practitioners address qualitative, or less scientific aspects of CRA involving values and preferences, along with quantitative information [148,149].

\subsection{Persistent Challenges in the Development and Practice of $C R A$}

Identifying and fostering the most useful approaches in the area of nonchemical stressors appears to be a persistent challenge in the development of CRA for human health. Clougherty and Kubzansky [24] reviewed the complexities in measuring social stress, which include the following:

- Developing good measures and biomarkers of stress while being cognizant of the phases of the stress response.

- Considering the temporal relationships between pollution exposure and stress.

- Accounting for the spatial correlation among social and physical or chemical exposures.

- Factoring in pollution and pollution sources as psychosocial stressors.

- Understanding that area-level socioeconomic data reflect many complex exposures, and physiological stress may or may not be closely related to all of them.

Additional challenges facing practitioners in planning effective CRAs also include:

- Modifying CRA frameworks to work at the community, state, and federal levels $[16,17]$.

- Identifying applicable data sources for the population of interest.

- Considering co-exposures that may be regulated by different agencies.

- Defining the scope of a CRA so that appropriate information from both ecological and human health risk studies can be effectively applied.

\subsection{Research and Data Needs}

Exposure assessment and dose-response are the quantitative inputs necessary to develop risk estimates. Work on identification of cumulative exposures is well-represented in this review. More work to improve our understanding of how to measure non-chemical stressor exposures and cumulative dose-response is needed. Many of the needs listed below address these research gaps. Findings and conclusions of several papers are reflected in the listing of research and data needs $[5,8,14,24,93,96,104,120,150-153]$. Research and data needs are organized into categories of human health, ecological health, and those that apply to both human and ecological health (including ecosystem services). Further research will help to identify the most useful of these approaches and indicators, and those that will be most effective in enhancing community involvement.

\subsubsection{Human Health}

- Careful attention to the measures and proxy variables for social or psychosocial stress, and AL.

- Toxicological research using animal models of social stress, including attention to the human relevance of such models. 
- Applications addressing exposures and health effects other than criteria air pollutants and related effects (mortality, respiratory diseases).

- Applications of GIS to examining health outcome questions/hypotheses (beyond using tools just to describe and identify areas of high combination exposure).

- Better understanding of short-term and long-term effects of exposure to nonchemical stressors.

\subsubsection{Ecological Health}

- Prioritization of the most important mixtures or combinations of stressors.

- Testing of more complex mixtures beyond two-stressor experiments.

- Attention to timing and sequence of exposures.

- Focus on collecting chronic mixture toxicity data.

- Long-term experiments to incorporate climate change projections, including adaptive potential to climate stress; habitat shifts or reduction; microevolution; and comparative studies of climate tolerance in reference populations and toxicant-resistant populations.

\subsubsection{Human and Ecological Health}

- Attention to susceptibility and vulnerability leading to the "cumulative dose-response."

- Dose-response modeling with advanced methods, such as fuzzy set theory, Bayesian modeling, and multi-level modeling.

- Biomarkers and mechanistic studies; calls for further work in toxicodynamics.

- Focus on multiple human health impacts of ecosystem degradation.

- Investigation of health outcomes resulting from the interaction of multiple environmental changes.

- Exploration of human adaptation to environmental changes and how this mediates health outcomes.

- Better characterization of populations affected by ecosystem alteration.

\section{Conclusions}

This article focused on presenting and highlighting research and methods from scientific literature to advance method development for conducting CRAs, and offers a synthesis of studies from a number of disciplines to serve as a reference to those interested in advancing the field of CRA. To provide a state of the practice and an overview of current methods and tools for CRA, a literature search was conducted using terms selected through consultation with EPA staff, and found many studies of cumulative risk problems in the science and practice literature from 2007 to 2016.

Studies contributing methods and applications for assessment of cumulative risks were gathered from varied subject areas including GIS, biomarkers, genetics, and "omics" research, social epidemiology, ecotoxicology, and climate change research. These studies supply evidence that health risks increase from combined exposures to chemical and nonchemical stressors or chemical mixtures. Important conceptual developments have been made in CRA and in disciplines supporting CRA (e.g., epidemiology and health geography) that strengthen the conceptual and theoretical frameworks necessary to improve characterization of cumulative risks. This article also identified many different disciplinary approaches and indices used to describe the social context for adverse outcomes. Staying abreast of new concepts and incorporating these concepts into CRAs will continue to be a challenge, however considerable improvements in the assessment of population health may be made as the evidence base for cumulative risks grows, measurements of social factors influencing risk are refined, and new concepts are incorporated into CRA's framework.

Supplementary Materials: The following are available online at www.mdpi.com/1660-4601/14/4/389/s1, Table S1: Cumulative exposure and risk concepts over time, Table S2: Conceptual developments-human health, Table S3: Cumulative risk methods and applications for human health: GIS, Table S4: Biomarker, genetic and "Omics" studies, Table S5: Measures and models, Table S6: Cumulative risk studies of vulnerable populations, 
Table S7: Conceptual developments—ecological health, Table S8: Measures and models—ecotoxicology, Table S9: Examples of ecological cumulative risk studies, Table S10: Conceptual developments-ecosystem services, Table S11: Methods and applications-ecosystem services, Table S12: Papers exploring essential concepts, methods and new directions.

Acknowledgments: Support for this study was provided by the U.S. EPA, Office of the Science Advisor, Risk Assessment Forum. Support was also provided in part by an appointment to the Research Participation Program in the Office of the Science Advisor, U.S. EPA, administered by the Oak Ridge Institute for Science and Education through an interagency agreement between the U.S. Department of Energy and U.S. EPA.

Author Contributions: Mary A. Fox wrote the first review for years 2007-2011. L. Elizabeth Brewer updated the work and wrote the second half of the review for years 2011-2016. Lawrence Martin conceived the scope for the article and advised on the selection of terms for the literature reviews. He wrote and/or revised the contextual description for the study, was the primary internal reviewer and editor, and contributed to conclusions and recommendations.

Conflicts of Interest: The authors declare no conflict of interest.

\section{Abbreviations}

The following abbreviations are used in this manuscript:

\begin{tabular}{|c|c|}
\hline AChE & acetylcholinesterase \\
\hline AL & allostatic load \\
\hline BMI & body mass index \\
\hline $\mathrm{CA}$ & concentration addition \\
\hline CAFO & concentrated animal feeding operation \\
\hline CAOS & common adverse outcomes \\
\hline CEQ & Council on Environmental Quality \\
\hline $\mathrm{CO}$ & carbon monoxide \\
\hline CRA & Cumulative Risk Assessment \\
\hline DA & dose addition \\
\hline DPSEEA & Driving Force-Pressure-State-Exposure-Effect-Action \\
\hline DPSIR & Drivers-Pressures-States-Impact-Response \\
\hline EFSA & European Food Safety Authority \\
\hline EM & effect modification \\
\hline EPA & U.S. Environmental Protection Agency \\
\hline FEV1 & forced expiratory volume in 1 second \\
\hline GIS & geographic information system \\
\hline $\mathrm{H} 2 \mathrm{~S}$ & hydrogen sulfide \\
\hline HAP & Hazardous Air Pollutant \\
\hline HIA & Health Impact Assessment \\
\hline IA & independent action \\
\hline LD50 & lethal dose, $50 \%$ \\
\hline $\mathrm{mmHg}$ & millimeter of mercury \\
\hline MOA & mode of action \\
\hline mRNA & messenger RNA \\
\hline NAAQS & National Ambient Air Quality Standards \\
\hline NEPA & National Environmental Policy Act \\
\hline NHANES & National Health and Nutrition Examination Survey \\
\hline $\mathrm{NO} 2$ & nitrogen dioxide \\
\hline NOx & nitrogen oxides \\
\hline NRC & National Research Council \\
\hline PAH & polyaromatic hydrocarbon \\
\hline PBPK & physiologically based pharmacokinetic \\
\hline PD & pharmacodynamic \\
\hline PK & pharmacokinetic \\
\hline PM & particulate matter \\
\hline $\mathrm{PM}_{10}$ & fine particulate matter (diameter $\leq 10 \mu \mathrm{m}$ ) \\
\hline $\mathrm{PM}_{2.5}$ & ultrafine particulate matter (diameter $\leq 2.5 \mu \mathrm{m}$ ) \\
\hline
\end{tabular}




$\begin{array}{ll}\text { RfD } & \text { reference dose } \\ \text { RWI } & \text { Relative Wellness Index } \\ \text { SEP } & \text { socioeconomic position } \\ \text { SES } & \text { socioeconomic status } \\ \text { TCDD } & \text { tetrachlorodibenzodioxin } \\ \text { TSP } & \text { total suspended particulates } \\ \text { VOC } & \text { volatile organic compound }\end{array}$

\section{References}

1. U.S. Environmental Protection Agency. Cumulative Risk Assessment Guidance. Part 1. Planning and Scoping. Available online: https://www.epa.gov/sites/production/files/2015-01/documents/cumrisk2_ 0.pdf (accessed on 29 November 2016).

2. U.S. Environmental Protection Agency. Framework for Cumulative Risk Assessment. Available online: https:/ / www.epa.gov/sites/production/files/2014-11/documents/frmwrk_cum_risk_assmnt.pdf (accessed on 29 November 2016).

3. National Research Council (NRC). Science and Decisions: Advancing Risk Assessment; National Academies Press: Washington, DC, USA, 2009.

4. Council on Environmental Quality (CEQ). Considering Cumulative Effects Under the National Environmental Policy Act. Available online: http://energy.gov/sites/prod/files/nepapub/nepa documents/RedDont/G-CEQ-ConsidCumulEffects.pdf (accessed on 29 November 2016).

5. Rider, C.V.; Dourson, M.L.; Hertzberg, R.C.; Mumtaz, M.M.; Price, P.S.; Simmons, J.E. Incorporating nonchemical stressors into cumulative risk assessments. Toxicol. Sci. 2012, 127, 10-17. [CrossRef] [PubMed]

6. European Food Safety Authority (EFSA). Scientific opinion on the relevance of dissimilar mode of action and its appropriate application for cumulative risk assessment of pesticides residues in food. EFSA J. 2013, 11,3472 .

7. National Research Council (NRC). Phthalates and Cumulative Risk Assessment: The Tasks Ahead; National Academies Press: Washington, DC, USA, 2008.

8. Lewis, A.S.; Sax, S.N.; Wason, S.C.; Campleman, S.L. Non-chemical stressors and cumulative risk assessment: An overview of current initiatives and potential air pollutant interactions. Int. J. Environ. Res. Public Health 2011, 8, 2020-2073. [CrossRef] [PubMed]

9. Ryan, P.B.; Burke, T.A.; Cohen Hubal, E.A.; Cura, J.J.; McKone, T.E. Using biomarkers to inform cumulative risk assessment. Environ. Health Perspect. 2007, 115, 833-840. [CrossRef] [PubMed]

10. Rider, C.V.; Furr, J.R.; Wilson, V.S.; Gray, L.E., Jr. Cumulative effects of in utero administration of mixtures of reproductive toxicants that disrupt common target tissues via diverse mechanisms of toxicity. Int. J. Androl. 2010, 33, 443-462. [CrossRef] [PubMed]

11. Checker, M. "But I know it's true": Environmental risk assessment, justice, and anthropology. Hum. Organ. 2007, 66, 112-124. [CrossRef]

12. Akom, A. Eco-apartheid: Linking environmental health to educational outcomes. Teach. Coll. Rec. 2011, 113, 831-859.

13. Cutchin, $M$. The need for the "new health geography" in epidemiologic studies of environment and health. Health Place 2007, 13, 725-742. [CrossRef] [PubMed]

14. Menzie, C.A.; MacDonell, M.M.; Mumtaz, M. A phased approach for assessing combined effects from multiple stressors. Environ. Health Perspect. 2007, 115, 807-816. [CrossRef] [PubMed]

15. Rider, C.V.; Boekelheide, K.; Catlin, N.; Gordon, C.J.; Morata, T.; Selgrade, M.K.; Sexton, K.; Simmons, J.E. Cumulative risk: Toxicity and interactions of physical and chemical stressors. Toxicol. Sci. 2013, 137, 3-11. [CrossRef] [PubMed]

16. Sexton, K. Cumulative health risk assessment: Finding new ideas and escaping from the old ones. Hum. Ecol. Risk Assess. Int. J. 2014, 21, 934-951. [CrossRef]

17. Barzyk, T.; Wilson, S.; Wilson, A. Community, state, and federal approaches to cumulative risk assessment: Challenges and opportunities for integration. Int. J. Environ. Res. Public Health 2015, 12, 4546-4571. [CrossRef] [PubMed] 
18. Lentz, T.J.; Dotson, G.S.; Williams, P.R.D.; Maier, A.; Gadagbui, B.; Pandalai, S.P.; Lamba, A.; Hearl, F.; Mumtaz, M. Aggregate exposure and cumulative risk assessment-Integrating occupational and non-occupational risk factors. J. Occup. Environ. Hyg. 2015, 12, S112-S126. [CrossRef] [PubMed]

19. Segal, D.; Lin, Y.-S.; Ginsberg, G.; Sonawane, B. A conceptual framework for evaluating the interaction of a chemical and nonchemical stressor in human health risk assessments: A case study for lead and psychosocial stress. Hum. Ecol. Risk Assess. Int. J. 2015, 21, 1840-1868. [CrossRef]

20. Smith, M.T.; de la Rosa, R.; Daniels, S.I. Using exposomics to assess cumulative risks and promote health. Environ. Mol. Mutagen. 2015, 56, 715-723. [CrossRef] [PubMed]

21. Braun, J.M.; Gennings, C.; Hauser, R.; Webster, T.F. What can epidemiological studies tell us about the impact of chemical mixtures on human health? EHP 2016, 124. [CrossRef] [PubMed]

22. Zeise, L.; Bois, F.Y.; Chiu, W.A.; Hattis, D.; Rusyn, I.; Guyton, K.Z. Addressing human variability in next-generation human health risk assessments of environmental chemicals. Environ. Health Perspect. 2013, 121, 23-31. [PubMed]

23. Beckie, T.M. A systematic review of allostatic load, health, and health disparities. Biol. Res. Nurs. 2012, 14, 311-346. [CrossRef] [PubMed]

24. Clougherty, J.E.; Kubzansky, L.D. A framework for examining social stress and susceptibility to air pollution in respiratory health. Environ. Health Perspect. 2009, 117, 1351-1358. [CrossRef] [PubMed]

25. Boon, P.E.; Van der Voet, H.; Van Raaij, M.T.M.; Van Klaveren, J.D. Cumulative risk assessment of the exposure to organophosphorus and carbamate insecticides in the Dutch diet. Food Chem. Toxicol. 2008, 46, 3090-3098. [CrossRef] [PubMed]

26. Bosgra, S.; Voet, H.V.D.; Boon, P.E.; Slob, W. An integrated probabilistic framework for cumulative risk assessment of common mechanism chemicals in food: An example with organophosphorus pesticides. Regul. Toxicol. Pharmacol. 2009, 54, 124-133. [CrossRef] [PubMed]

27. Tsoutsi, C.S.; Konstantinou, I.K.; Hela, D.G. Organophosphorus pesticide residues in Greek virgin olive oil: Levels, dietary intake and risk assessment. Food Addit. Contam.: Part A 2008, 25, 1225-1236. [CrossRef] [PubMed]

28. Bosgra, S.; van der Voet, H.; Boon, P.; Müller, A.K.; Bos, P.; Slob, W. An integrated framework for probabilistic cumulative risk assessment of chemicals in food. Toxicol. Lett. 2007, 172, S100-S101. [CrossRef]

29. Bosgra, S.; van Eijkeren, J.C.H.; Slob, W. Dose addition and the isobole method as approaches for predicting the cumulative effect of non-interacting chemicals: A critical evaluation. Crit. Rev. Toxicol. 2009, 39, 418-426. [CrossRef] [PubMed]

30. Bosgra, S.; van Eijkeren, J.C.H.; van der Schans, M.J.; Langenberg, J.P.; Slob, W. Toxicodynamic analysis of the combined cholinesterase inhibition by paraoxon and methamidophos in human whole blood. Toxicol. Appl. Pharmacol. 2009, 236, 9-15. [CrossRef] [PubMed]

31. Bosgra, S.; van Eijkeren, J.C.H.; van der Schans, M.J.; Langenberg, J.P.; Slob, W. Toxicodynamic analysis of the inhibition of isolated human acetylcholinesterase by combinations of methamidophos and methomyl in vitro. Toxicol. Appl. Pharmacol. 2009, 236, 1-8. [CrossRef] [PubMed]

32. Müller, A.K.; Bosgra, S.; Boon, P.E.; Voet, H.V.D.; Nielsen, E.; Ladefoged, O. Probabilistic cumulative risk assessment of anti-androgenic pesticides in food. Food Chem. Toxicol. 2009, 47, 2951-2962. [CrossRef] [PubMed]

33. Abdo, N.; Wetmore, B.A.; Chappell, G.A.; Shea, D.; Wright, F.A.; Rusyn, I. In vitro screening for population variability in toxicity of pesticide-containing mixtures. Environ. Int. 2015, 85, 147-155. [CrossRef] [PubMed]

34. Jensen, B.H.; Petersen, A.; Nielsen, E.; Christensen, T.; Poulsen, M.E.; Andersen, J.H. Cumulative dietary exposure of the population of Denmark to pesticides. Food Chem. Toxicol. 2015, 83, 300-307. [CrossRef] [PubMed]

35. Kennedy, M.C.; van der Voet, H.; Roelofs, V.J.; Roelofs, W.; Glass, C.R.; de Boer, W.J.; Kruisselbrink, J.W.; Hart, A.D.M. New approaches to uncertainty analysis for use in aggregate and cumulative risk assessment of pesticides. Food Chem. Toxicol. 2015, 79, 54-64. [CrossRef] [PubMed]

36. Moretto, A.; Di Renzo, F.; Giavini, E.; Metruccio, F.; Menegola, E. The use of in vitro testing to refine cumulative assessment groups of pesticides: The example of teratogenic conazoles. Food Chem. Toxicol. 2015, 79, 65-69. [CrossRef] [PubMed]

37. Dewalque, L.; Charlier, C.; Pirard, C. Estimated daily intake and cumulative risk assessment of phthalate diesters in a Belgian general population. Toxicol. Lett. 2014, 231, 161-168. [CrossRef] [PubMed] 
38. Hartmann, C.; Uhl, M.; Weiss, S.; Koch, H.M.; Scharf, S.; König, J. Human biomonitoring of phthalate exposure in Austrian children and adults and cumulative risk assessment. Int. J. Hyg. Environ. Health 2015, 218, 489-499. [CrossRef] [PubMed]

39. Wang, B.; Wang, H.; Zhou, W.; Chen, Y.; Zhou, Y.; Jiang, Q. Urinary excretion of phthalate metabolites in school children of China: Implication for cumulative risk assessment of phthalate exposure. Environ. Sci. Technol. 2015, 49, 1120-1129. [CrossRef] [PubMed]

40. Pelallo-Martínez, N.A.; Batres-Esquivel, L.; Carrizales-Yáñez, L.; Díaz-Barriga, F.M. Genotoxic and hematological effects in children exposed to a chemical mixture in a petrochemical area in Mexico. Arch. Environ. Contam. Toxicol. 2014, 67, 1-8. [CrossRef] [PubMed]

41. Maffini, M.V.; Neltner, T.G. Brain drain: The cost of neglected responsibilities in evaluating cumulative effects of environmental chemicals. J. Epidemiol. Community Health 2014, 69, 496-499. [CrossRef] [PubMed]

42. Claus Henn, B.; Coull, B.A.; Wright, R.O. Chemical mixtures and children's health. Curr. Opin. Pediatr. 2014, 26, 223-229. [CrossRef] [PubMed]

43. Lee, D.-H.; Jacobs, D.R. Hormesis and public health: Can glutathione depletion and mitochondrial dysfunction due to very low-dose chronic exposure to persistent organic pollutants be mitigated? J. Epidemiol. Community Health 2014, 69, 294-300. [CrossRef] [PubMed]

44. Orton, F.; Ermler, S.; Kugathas, S.; Rosivatz, E.; Scholze, M.; Kortenkamp, A. Mixture effects at very low doses with combinations of anti-androgenic pesticides, antioxidants, industrial pollutant and chemicals used in personal care products. Toxicol. Appl. Pharmacol. 2014, 278, 201-208. [CrossRef] [PubMed]

45. Ge, Y.; Bruno, M.; Wallace, K.; Leavitt, S.; Andrews, D.; Spassova, M.A.; Xi, M.; Roy, A.; Haykal-Coates, N.; Lefew, W.; et al. Systematic proteomic approach to characterize the impacts of chemical interactions on protein and cytotoxicity responses to metal mixture exposures. J. Proteome Res. 2015, 14, 183-192. [CrossRef] [PubMed]

46. Hadrup, N. Evidence from pharmacology and pathophysiology suggests that chemicals with dissimilar mechanisms of action could be of bigger concern in the toxicological risk assessment of chemical mixtures than chemicals with a similar mechanism of action. Regul. Toxicol. Pharmacol. 2014, 69, 281-283. [CrossRef] [PubMed]

47. Basara, H.G.; Yuan, M. Community health assessment using self-organizing maps and geographic information systems. Int. J. Health Geogr. 2008, 7, 67. [CrossRef] [PubMed]

48. Briggs, D.; Abellan, J.J.; Fecht, D. Environmental inequity in England: Small area associations between socio-economic status and environmental pollution. Soc. Sci. Med. 2008, 67, 1612-1629. [CrossRef] [PubMed]

49. Salinas, J.J.; Shah, M.; Abdelbary, B.; Gay, J.L.; Sexton, K. Application of a novel method for assessing cumulative risk burden by county. Int. J. Environ. Res. Public Health 2012, 9, 1820-1835. [CrossRef] [PubMed]

50. Huang, G.; London, J.K. Cumulative environmental vulnerability and environmental justice in California's San Joaquin Valley. Int. J. Environ. Res. Public Health 2012, 9, 1593-1608. [CrossRef] [PubMed]

51. Alexeeff, G.V.; Faust, J.B.; August, L.M.; Milanes, C.; Randles, K.; Zeise, L.; Denton, J. A screening method for assessing cumulative impacts. Int. J. Environ. Res. Public Health 2012, 9, 648-659. [CrossRef] [PubMed]

52. McDonald, Y.J.; Grineski, S.E.; Collins, T.W.; Kim, Y.-A. A scalable climate health justice assessment model. Soc. Sci. Med. 2015, 133, 242-252. [CrossRef] [PubMed]

53. Shmool, J.L.C.; Kubzansky, L.D.; Dotson Newman, O.; Spengler, J.; Shepard, P.; Clougherty, J.E. Social stressors and air pollution across New York city communities: A spatial approach for assessing correlations among multiple exposures. Environ. Health 2014, 13. [CrossRef] [PubMed]

54. Al Zabadi, H.; Ferrari, L.; Sari-Minodier, I.; Kerautret, M.-A.; Tiberguent, A.; Paris, C.; Zmirou-Navier, D. Integrated exposure assessment of sewage workers to genotoxicants: An urinary biomarker approach and oxidative stress evaluation. Environ. Health 2011, 10. [CrossRef] [PubMed]

55. Das, P.; Shaik, A.; Jamil, K. Genotoxicity induced by pesticide mixtures: In-vitro studies on human peripheral blood lymphocytes. Toxicol. Ind. Health 2007, 23, 449-458. [CrossRef] [PubMed]

56. Whyatt, R.M.; Liu, X.; Rauh, V.A.; Calafat, A.M.; Just, A.C.; Hoepner, L.; Diaz, D.; Quinn, J.; Adibi, J.; Perera, F.P.; et al. Maternal prenatal urinary phthalate metabolite concentrations and child mental, psychomotor, and behavioral development at 3 years of age. Environ. Health Perspect. 2011, 120, $290-295$. [CrossRef] [PubMed] 
57. Zota, A.R.; Park, J.-S.; Wang, Y.; Petreas, M.; Zoeller, R.T.; Woodruff, T.J. Polybrominated diphenyl ethers, hydroxylated polybrominated diphenyl ethers, and measures of thyroid function in second trimester pregnant women in California. Environ. Sci. Technol. 2011, 45, 7896-7905. [CrossRef] [PubMed]

58. Hendriksen, P.J.M.; Freidig, A.P.; Jonker, D.; Thissen, U.; Bogaards, J.J.P.; Mumtaz, M.M.; Groten, J.P.; Stierum, R.H. Transcriptomics analysis of interactive effects of benzene, trichloroethylene and methyl mercury within binary and ternary mixtures on the liver and kidney following subchronic exposure in the rat. Toxicol. Appl. Pharmacol. 2007, 225, 171-188. [CrossRef] [PubMed]

59. North, K.E.; Martin, L.J. The importance of gene-environment interaction: Implications for social scientists. Sociol. Methods Res. 2008, 37, 164-200. [CrossRef]

60. Thayer, Z.M.; Kuzawa, C.W. Biological memories of past environments: Epigenetic pathways to health disparities. Epigenetics 2011, 6, 798-803. [CrossRef] [PubMed]

61. Daughton, C.G. Using biomarkers in sewage to monitor community-wide human health: Isoprostanes as conceptual prototype. Sci. Total Environ. 2012, 424, 16-38. [CrossRef] [PubMed]

62. Gennings, C.; Ellis, R.; Ritter, J.K. Linking empirical estimates of body burden of environmental chemicals and wellness using NHANES data. Environ. Int. 2012, 39, 56-65. [CrossRef] [PubMed]

63. Bonefeld-Jørgensen, E.C.; Ghisari, M.; Wielsøe, M.; Bjerregaard-Olesen, C.; Kjeldsen, L.S.; Long, M. Biomonitoring and hormone-disrupting effect biomarkers of persistent organic pollutantsin vitroandex vivo. Basic Clin. Pharmacol. Toxicol. 2014, 115, 118-128. [CrossRef] [PubMed]

64. Juarez, P.; Matthews-Juarez, P.; Hood, D.; Im, W.; Levine, R.; Kilbourne, B.; Langston, M.; Al-Hamdan, M.; Crosson, W.; Estes, M.; et al. The public health exposome: A population-based, exposure science approach to health disparities research. Int. J. Environ. Res. Public Health 2014, 11, 12866-12895. [CrossRef] [PubMed]

65. Medina-Vera, M.; Van Emon, J.M.; Melnyk, L.J.; Bradham, K.D.; Harper, S.L.; Morgan, J.N. An overview of measurement method tools available to communities for conducting exposure and cumulative risk assessments. J. Expo. Sci. Environ. Epidemiol. 2009, 20, 359-370. [CrossRef] [PubMed]

66. Barzyk, T.M.; Conlon, K.C.; Chahine, T.; Hammond, D.M.; Zartarian, V.G.; Schultz, B.D. Tools available to communities for conducting cumulative exposure and risk assessments. J. Expo. Sci. Environ. Epidemiol. 2010, 20, 371-384. [CrossRef] [PubMed]

67. MacDonell, M.M.; Haroun, L.A.; Teuschler, L.K.; Rice, G.E.; Hertzberg, R.C.; Butler, J.P.; Chang, Y.-S.; Clark, S.L.; Johns, A.P.; Perry, C.S.; et al. Cumulative risk assessment toolbox: Methods and approaches for the practitioner. J. Toxicol. 2013, 2013, 1-36. [CrossRef] [PubMed]

68. Glass, T.A.; Bandeen-Roche, K.; McAtee, M.; Bolla, K.; Todd, A.C.; Schwartz, B.S. Neighborhood psychosocial hazards and the association of cumulative lead dose with cognitive function in older adults. Am. J. Epidemiol. 2009, 169, 683-692. [CrossRef] [PubMed]

69. Su, J.G.; Morello-Frosch, R.; Jesdale, B.M.; Kyle, A.D.; Shamasunder, B.; Jerrett, M. An index for assessing demographic inequalities in cumulative environmental hazards with application to Los Angeles, California. Environ. Sci. Technol. 2009, 43, 7626-7634. [CrossRef] [PubMed]

70. Glei, D.A.; Goldman, N.; Chuang, Y.-L.; Weinstein, M. Do chronic stressors lead to physiological dysregulation? Testing the theory of allostatic load. Psychosom. Med. 2007, 69, 769-776. [CrossRef] [PubMed]

71. Zota, A.R.; Shenassa, E.D.; Morello-Frosch, R. Allostatic load amplifies the effect of blood lead levels on elevated blood pressure among middle-aged U.S. adults: A cross-sectional study. Environ. Health 2013, 12. [CrossRef] [PubMed]

72. Clougherty, J.E.; Rossi, C.A.; Lawrence, J.; Long, M.S.; Diaz, E.A.; Lim, R.H.; McEwen, B.; Koutrakis, P.; Godleski, J.J. Chronic social stress and susceptibility to concentrated ambient fine particles in rats. Environ. Health Perspect. 2010, 118, 769-775. [CrossRef] [PubMed]

73. Levy, J.I.; Fabian, M.P.; Peters, J.L. Meta-Analytic approaches for multistressor dose-response function development: Strengths, limitations, and case studies. Risk Anal. 2014, 35, 1040-1049. [CrossRef] [PubMed]

74. Wason, S.C.; Smith, T.J.; Perry, M.J.; Levy, J.I. Using physiologically-based pharmacokinetic models to incorporate chemical and non-chemical stressors into cumulative risk assessment: A case study of pesticide exposures. Int. J. Environ. Res. Public Health 2012, 9, 1971-1983. [CrossRef] [PubMed]

75. Kondo, M.C.; Gross-Davis, C.A.; May, K.; Davis, L.O.; Johnson, T.; Mallard, M.; Gabbadon, A.; Sherrod, C.; Branas, C.C. Place-based stressors associated with industry and air pollution. Health Place 2014, 28, 31-37. [CrossRef] [PubMed] 
76. Evans, A.; Rice, G.; Teuschler, L.; Wright, J. Joint exposure to chemical and nonchemical neurodevelopmental stressors in U.S. women of reproductive age in NHANES. Int. J. Environ. Res. Public Health 2014, 11, 4384-4401. [CrossRef] [PubMed]

77. Schwartz, J.; Bellinger, D.; Glass, T. Exploring potential sources of differential vulnerability and susceptibility in risk from environmental hazards to expand the scope of risk assessment. Am. J. Public Health 2011, 101, S94-S101. [CrossRef] [PubMed]

78. Theall, K.P.; Brett, Z.H.; Shirtcliff, E.A.; Dunn, E.C.; Drury, S.S. Neighborhood disorder and telomeres: Connecting children's exposure to community level stress and cellular response. Soc. Sci. Med. 2013, 85, 50-58. [CrossRef] [PubMed]

79. Dulin-Keita, A.; Casazza, K.; Fernandez, J.R.; Goran, M.I.; Gower, B. Do neighbourhoods matter? Neighbourhood disorder and long-term trends in serum cortisol levels. J. Epidemiol. Community Health 2010, 66, 24-29. [CrossRef] [PubMed]

80. Pearlman, D.N. Neighborhood-Level risk and resilience factors: An emerging issue in childhood asthma epidemiology. Expert Rev. Clin. Immunol. 2009, 5, 633-637. [CrossRef] [PubMed]

81. Chen, E.; Schreier, H.M.C.; Strunk, R.C.; Brauer, M. Chronic traffic-related air pollution and stress interact to predict biologic and clinical outcomes in asthma. Environ. Health Perspect. 2008, 116, 970-975. [CrossRef] [PubMed]

82. Islam, T.; Urman, R.; Gauderman, W.J.; Milam, J.; Lurmann, F.; Shankardass, K.; Avol, E.; Gilliland, F.; McConnell, R. Parental stress increases the detrimental effect of traffic exposure on children's lung function. Am. J. Respir. Crit. Care Med. 2011, 184, 822-827. [CrossRef] [PubMed]

83. Shankardass, K.; McConnell, R.; Jerrett, M.; Milam, J.; Richardson, J.; Berhane, K. Parental stress increases the effect of traffic-related air pollution on childhood asthma incidence. Proc. Natl. Acad. Sci. USA 2009, 106, 12406-12411. [CrossRef] [PubMed]

84. Hoffmann, B.; Kolahgar, B.; Rauchfuss, K.; Eberwein, G.; Franzen-Reuter, I.; Kraft, M.; Wilhelm, M.; Ranft, U.; Jöckel, K.-H. Childhood social position and associations between environmental exposures and health outcomes. Int. J. Hyg. Environ. Health 2009, 212, 146-156. [CrossRef] [PubMed]

85. Wright, R.J.; Suglia, S.F.; Levy, J.; Fortun, K.; Shields, A.; Subramanian, S.V.; Wright, R. Transdisciplinary research strategies for understanding socially patterned disease: The asthma coalition on community, environment, and social stress (access) project as a case study. Ciência Saúde Coletiva 2008, 13, 1729-1742. [CrossRef] [PubMed]

86. Erickson, A.C.; Arbour, L. The shared pathoetiological effects of particulate air pollution and the social environment on fetal-placental development. J. Environ. Public Health 2014, 2014, 1-20. [CrossRef] [PubMed]

87. Bevc, C.A.; Marshall, B.K.; Picou, J.S. Environmental justice and toxic exposure: Toward a spatial model of physical health and psychological well-being. Soc. Sci. Res. 2007, 36, 48-67. [CrossRef]

88. Wing, S.; Horton, R.A.; Muhammad, N.; Grant, G.R.; Tajik, M.; Thu, K. Integrating epidemiology, education, and organizing for environmental justice: Community health effects of industrial hog operations. Am. J. Public Health 2008, 98, 1390-1397. [CrossRef] [PubMed]

89. Horton, R.A.; Wing, S.; Marshall, S.W.; Brownley, K.A. Malodor as a trigger of stress and negative mood in neighbors of industrial hog operations. Am. J. Public Health 2009, 99, S610-S615. [CrossRef] [PubMed]

90. Schinasi, L.; Horton, R.A.; Guidry, V.T.; Wing, S.; Marshall, S.W.; Morland, K.B. Air pollution, lung function, and physical symptoms in communities near concentrated swine feeding operations. Epidemiology 2011, 22, 208-215. [CrossRef] [PubMed]

91. Wing, S.; Horton, R.A.; Rose, K.M. Air pollution from industrial swine operations and blood pressure of neighboring residents. Environ. Health Perspect. 2013, 121, 92-96. [PubMed]

92. Schüle, S.A.; Bolte, G. Interactive and independent associations between the socioeconomic and objective built environment on the neighbourhood level and individual health: A systematic review of multilevel studies. PLoS ONE 2015, 10, e0123456. [CrossRef] [PubMed]

93. Holmstrup, M.; Bindesbøl, A.-M.; Oostingh, G.J.; Duschl, A.; Scheil, V.; Köhler, H.-R.; Loureiro, S.; Soares, A.M.V.M.; Ferreira, A.L.G.; Kienle, C.; et al. Interactions between effects of environmental chemicals and natural stressors: A review. Sci. Total Environ. 2010, 408, 3746-3762. [CrossRef] [PubMed]

94. Løkke, H. Novel methods for integrated risk assessment of cumulative stressors-Results from the NOMIRACLE project. Sci. Total Environ. 2010, 408, 3719-3724. [CrossRef] [PubMed] 
95. Jansen, M.; Coors, A.; Stoks, R.; De Meester, L. Evolutionary ecotoxicology of pesticide resistance: A case study in Daphnia. Ecotoxicology 2011, 20, 543-551. [CrossRef] [PubMed]

96. Moe, S.J.; De Schamphelaere, K.; Clements, W.H.; Sorensen, M.T.; Van den Brink, P.J.; Liess, M. Combined and interactive effects of global climate change and toxicants on populations and communities. Environ. Toxicol. Chem. 2012, 32, 49-61. [CrossRef] [PubMed]

97. Dondero, F.; Negri, A.; Boatti, L.; Marsano, F.; Mignone, F.; Viarengo, A. Transcriptomic and proteomic effects of a neonicotinoid insecticide mixture in the marine mussel (Mytilus galloprovincialis, Lam.). Sci. Total Environ. 2010, 408, 3775-3786. [CrossRef] [PubMed]

98. Wang, Z.; Chen, J.; Huang, L.; Wang, Y.; Cai, X.; Qiao, X.; Dong, Y. Integrated fuzzy concentration addition-independent action (IFCA-IA) model outperforms two-stage prediction (TSP) for predicting mixture toxicity. Chemosphere 2009, 74, 735-740. [CrossRef] [PubMed]

99. Zhang, Y.-H.; Liu, S.-S.; Liu, H.-L.; Liu, Z.-Z. Evaluation of the combined toxicity of 15 pesticides by uniform design. Pest Manag. Sci. 2010, 66, 879-887. [CrossRef] [PubMed]

100. Al-Salhi, R.; Abdul-Sada, A.; Lange, A.; Tyler, C.R.; Hill, E.M. The xenometabolome and novel contaminant markers in fish exposed to a wastewater treatment works effluent. Environ. Sci. Technol. 2012, 46, 9080-9088. [CrossRef] [PubMed]

101. Garcia-Reyero, N.; Escalon, B.L.; Loh, P.R.; Laird, J.G.; Kennedy, A.J.; Berger, B.; Perkins, E.J. Assessment of chemical mixtures and groundwater effects on Daphnia magna transcriptomics. Environ. Sci. Technol. 2012, 46, 42-50. [CrossRef] [PubMed]

102. Baylay, A.J.; Spurgeon, D.J.; Svendsen, C.; Griffin, J.L.; Swain, S.C.; Sturzenbaum, S.R.; Jones, O.A.H. A metabolomics based test of independent action and concentration addition using the earthworm Lumbricus rubellus. Ecotoxicology 2012, 21, 1436-1447. [CrossRef] [PubMed]

103. Coors, A.; De Meester, L. Synergistic, antagonistic and additive effects of multiple stressors: Predation threat, parasitism and pesticide exposure in Daphnia magna. J. Appl. Ecol. 2008, 45, 1820-1828. [CrossRef]

104. Ferreira, A.L.G.; Loureiro, S.; Soares, A.M.V.M. Toxicity prediction of binary combinations of cadmium, carbendazim and low dissolved oxygen on Daphnia magna. Aquat. Toxicol. 2008, 89, 28-39. [CrossRef] [PubMed]

105. Cedergreen, N.; Christensen, A.M.; Kamper, A.; Kudsk, P.; Mathiassen, S.K.; Streibig, J.C.; Sørensen, H. A review of independent action compared to concentration addition as reference models for mixtures of compounds with different molecular target sites. Environ. Toxicol. Chem. 2008, 27, 1621. [CrossRef] [PubMed]

106. Gregorio, V.; Chèvre, N.; Junghans, M. Critical issues in using the common mixture toxicity models concentration addition or response addition on species sensitivity distributions: A theoretical approach. Environ. Toxicol. Chem. 2013, 32, 2387-2395. [CrossRef] [PubMed]

107. Rodney, S.I.; Teed, R.S.; Moore, D.R.J. Estimating the toxicity of pesticide mixtures to aquatic organisms: A review. Hum. Ecol. Risk Assess. Int. J. 2013, 19, 1557-1575. [CrossRef]

108. Kamo, M.; Yokomizo, H. Explanation of non-additive effects in mixtures of similar mode of action chemicals. Toxicology 2015, 335, 20-26. [CrossRef] [PubMed]

109. Backhaus, T.; Faust, M. Predictive environmental risk assessment of chemical mixtures: A conceptual framework. Environm. Sci. Technol. 2012, 46, 2564-2573. [CrossRef] [PubMed]

110. Altenburger, R.; Backhaus, T.; Boedeker, W.; Faust, M.; Scholze, M. Simplifying complexity: Mixture toxicity assessment in the last 20 years. Environ. Toxicol. Chem. 2013, 32, 1685-1687. [CrossRef] [PubMed]

111. Langmead, O.; McQuatters-Gollop, A.; Mee, L.D.; Friedrich, J.; Gilbert, A.J.; Gomoiu, M.-T.; Jackson, E.L.; Knudsen, S.; Minicheva, G.; Todorova, V. Recovery or decline of the northwestern black sea: A societal choice revealed by socio-ecological modelling. Ecol. Modell. 2009, 220, 2927-2939. [CrossRef]

112. Landis, W.G.; Ayre, K.K.; Johns, A.F.; Summers, H.M.; Stinson, J.; Harris, M.J.; Herring, C.E.; Markiewicz, A.J. The multiple stressor ecological risk assessment for the mercury contaminated South River and Upper Shenandoah River using the Bayesian network-relative risk model. Integr. Environ. Assess. Manag. 2016. [CrossRef] [PubMed]

113. Dietrich, J.P.; Van Gaest, A.L.; Strickland, S.A.; Arkoosh, M.R. The impact of temperature stress and pesticide exposure on mortality and disease susceptibility of endangered pacific salmon. Chemosphere 2014, 108, 353-359. [CrossRef] [PubMed] 
114. Stampfli, N.C.; Knillmann, S.; Liess, M.; Noskov, Y.A.; Schäfer, R.B.; Beketov, M.A. Two stressors and a community-Effects of hydrological disturbance and a toxicant on freshwater zooplankton. Aquat. Toxicol. 2013, 127, 9-20. [CrossRef] [PubMed]

115. Vieira, L.R.; Guilhermino, L. Multiple stress effects on marine planktonic organisms: Influence of temperature on the toxicity of polycyclic aromatic hydrocarbons to Tetraselmis chuii. J. Sea Res. 2012, 72, 94-98. [CrossRef]

116. Vidau, C.; Diogon, M.; Aufauvre, J.; Fontbonne, R.; Viguès, B.; Brunet, J.-L.; Texier, C.; Biron, D.G.; Blot, N.; El Alaoui, H.; et al. Exposure to sublethal doses of fipronil and thiacloprid highly increases mortality of honeybees previously infected by Nosema ceranae. PLOS ONE 2011, 6, e21550. [CrossRef] [PubMed]

117. Millennium Ecosystem Assessment (MEA). Ecosystems and Human Well-Being: Synthesis; Island Press: Washington, DC, USA, 2005.

118. U.S. Environmental Protection Agency. Generic Ecological Assessment Endpoints (GEAEs) for Ecological Risk Assessment. Available online: https:/ /www.epa.gov/sites/production/files/2014-11/documents / generic_endpoinsts_2004.pdf (accessed on 29 November 2016).

119. Munns, W.R.; Rea, A.W.; Suter, G.W.; Martin, L.; Blake-Hedges, L.; Crk, T.; Davis, C.; Ferreira, G.; Jordan, S.; Mahoney, M.; et al. Ecosystem services as assessment endpoints for ecological risk assessment. Integr. Environ. Assess. Manag. 2015, 12, 522-528. [CrossRef] [PubMed]

120. Myers, S.S.; Gaffikin, L.; Golden, C.D.; Ostfeld, R.S.; Redford, K.H.; Ricketts, T.H.; Turner, W.R.; Osofsky, S.A. Human health impacts of ecosystem alteration. Proc. Natl. Acad. Sci. USA 2013, 110, 18753-18760. [CrossRef] [PubMed]

121. Reis, S.; Morris, G.; Fleming, L.E.; Beck, S.; Taylor, T.; White, M.; Depledge, M.H.; Steinle, S.; Sabel, C.E.; Cowie, H.; et al. Integrating health and environmental impact analysis. Public Health 2015, 129, 1383-1389. [CrossRef] [PubMed]

122. De Laender, F.; Janssen, C.R. Brief communication: The ecosystem perspective in ecotoxicology as a way forward for the ecological risk assessment of chemicals. Integr. Environ. Assess. Manag. 2013, 9, e34-e38. [CrossRef] [PubMed]

123. Ringold, P.L.; Boyd, J.; Landers, D.; Weber, M. What data should we collect? A framework for identifying indicators of ecosystem contributions to human well-being. Front. Ecol. Environ. 2013, 11, 98-105. [CrossRef]

124. Norman, L.M.; Villarreal, M.L.; Lara-Valencia, F.; Yuan, Y.; Nie, W.; Wilson, S.; Amaya, G.; Sleeter, R. Mapping socio-environmentally vulnerable populations access and exposure to ecosystem services at the U.S.-Mexico borderlands. Appl. Geogr. 2012, 34, 413-424. [CrossRef]

125. National Institutes of Health $(\mathrm{NIH})$. The National Children's Study Archive Study Description and Guide. Available online: https://www.nichd.nih.gov/research/NCS/Pages/default.aspx (accessed on 23 November 2016).

126. Kim, B.M.; Ha, M.; Park, H.S.; Lee, B.E.; Kim, Y.J.; Hong, Y.C.; Kim, Y.; Chang, N.; Roh, Y.M.; Kim, B.N.; et al. The mothers and children's environmental health (MOCEH) study. Eur. J. Epidemiol. 2009, 24, 573-583. [CrossRef] [PubMed]

127. Bhang, S.; Ha, E.; Park, H.; Ha, M.; Hong, Y.C.; Kim, B.N.; Lee, S.J.; Lee, K.Y.; Kim, J.H.; Jeong, J.; et al. Maternal stress and depressive symptoms and infant development at six months: The mothers and children's environmental health (MOCEH) prospective study. J. Korean Med. Sci. 2016, 31, 843. [CrossRef] [PubMed]

128. Wishart, D.; Arndt, D.; Pon, A.; Sajed, T.; Guo, A.C.; Djoumbou, Y.; Knox, C.; Wilson, M.; Liang, Y.; Grant, J.; et al. T3DB: The toxic exposome database. Nucleic Acids Res. 2014, 43, D928-D934. [CrossRef] [PubMed]

129. Fox, M.A.; Groopman, J.D.; Burke, T.A. Evaluating cumulative risk assessment for environmental justice: A community case study. Environ. Health Perspect. 2001, 110, 203-209. [CrossRef]

130. Borgert, C.J.; Sargent, E.V.; Casella, G.; Dietrich, D.R.; McCarty, L.S.; Golden, R.J. The human relevant potency threshold: Reducing uncertainty by human calibration of cumulative risk assessments. Regul. Toxicol. Pharmacol. 2012, 62, 313-328. [CrossRef] [PubMed]

131. Balbus, J.M.; Boxall, A.B.A.; Fenske, R.A.; McKone, T.E.; Zeise, L. Implications of global climate change for the assessment and management of human health risks of chemicals in the natural environment. Environ. Toxicol. Chem. 2012, 32, 62-78. [CrossRef] [PubMed]

132. McEwen, B.S.; Tucker, P. Critical biological pathways for chronic psychosocial stress and research opportunities to advance the consideration of stress in chemical risk assessment. Am. J. Public Health 2011, 101, S131-S139. [CrossRef] [PubMed] 
133. Hennig, B.; Ormsbee, L.; McClain, C.J.; Watkins, B.A.; Blumberg, B.; Bachas, L.G.; Sanderson, W.; Thompson, C.; Suk, W.A. Nutrition can modulate the toxicity of environmental pollutants: Implications in risk assessment and human health. Environ. Health Perspect. 2012, 120, 771-774. [CrossRef] [PubMed]

134. Smith, L.M.; Case, J.L.; Smith, H.M.; Harwell, L.C.; Summers, J.K. Relating ecosystem services to domains of human well-being: Foundation for a U.S. index. Ecol. Indic. 2013, 28, 79-90. [CrossRef]

135. Andrey, J.; Jones, B. The dynamic nature of social disadvantage: Implications for hazard exposure and vulnerability in Greater Vancouver. Can. Geogr. 2008, 52, 146-168. [CrossRef]

136. Boyd, J.; Vrana, J.A.; Williams, H.N. In vitro approach to predict post-translational phosphorylation response to mixtures. Toxicology 2013, 313, 113-121. [CrossRef] [PubMed]

137. Zartarian, V.G.; Schultz, B.D. The EPA'S human exposure research program for assessing cumulative risk in communities. J. Expo. Sci. Environ. Epidemiol. 2009, 20, 351-358. [CrossRef] [PubMed]

138. Zartarian, V.G.; Schultz, B.D.; Barzyk, T.M.; Smuts, M.; Hammond, D.M.; Medina-Vera, M.; Geller, A.M. The environmental protection agency's community-focused exposure and risk screening tool (C-FERST) and its potential use for environmental justice efforts. Am. J. Public Health 2011, 101, S286-S294. [CrossRef] [PubMed]

139. Hicken, M.T.; Gee, G.C.; Connell, C.; Snow, R.C.; Morenoff, J.; Hu, H. Black-white blood pressure disparities: Depressive symptoms and differential vulnerability to blood lead. Environ. Health Perspect. 2013, 121, 205-209. [PubMed]

140. Young, G.S.; Fox, M.A.; Trush, M.; Kanarek, N.; Glass, T.A.; Curriero, F.C. Differential exposure to hazardous air pollution in the United States: A multilevel analysis of urbanization and neighborhood socioeconomic deprivation. Int. J. Environ. Res. Public Health 2012, 9, 2204-2225. [CrossRef] [PubMed]

141. Navas-Acien, A.; Tellez-Plaza, M.; Guallar, E.; Muntner, P.; Silbergeld, E.; Jaar, B.; Weaver, V. Blood cadmium and lead and chronic kidney disease in U.S. adults: A joint analysis. Am. J. Epidemiol. 2009, 170, 1156-1164. [CrossRef] [PubMed]

142. McConnachie, S.H.; O'Connor, C.M.; Gilmour, K.M.; Iwama, G.K.; Cooke, S.J. Supraphysiological cortisol elevation alters the response of wild bluegill sunfish to subsequent stressors. J. Exp. Zool. Part A: Ecol. Genet. Physiol. 2012, 317, 321-332. [CrossRef] [PubMed]

143. Morello-Frosch, R.; Zuk, M.; Jerrett, M.; Shamasunder, B.; Kyle, A.D. Understanding the cumulative impacts of inequalities in environmental health: Implications for policy. Health Aff. 2011, 30, 879-887. [CrossRef] [PubMed]

144. Wernham, A. Inupiat health and proposed Alaskan oil development: Results of the first integrated health impact assessment/environmental impact statement for proposed oil development on Alaska's north slope. EcoHealth 2007, 4, 500-513. [CrossRef]

145. Health Impact Project. Health Impact Project: Advancing Smarter Policies for Healthier Communities. Available online: http:/ / www.healthimpactproject.org/ (accessed on 29 November 2016).

146. Ankley, G.T.; Bennett, R.S.; Erickson, R.J.; Hoff, D.J.; Hornung, M.W.; Johnson, R.D.; Mount, D.R.; Nichols, J.W.; Russom, C.L.; Schmieder, P.K.; et al. Adverse outcome pathways: A conceptual framework to support ecotoxicology research and risk assessment. Environ. Toxicol. Chem. 2010, 29, 730-741. [CrossRef] [PubMed]

147. Villeneuve, D.L.; Crump, D.; Garcia-Reyero, N.; Hecker, M.; Hutchinson, T.H.; LaLone, C.A.; Landesmann, B.; Lettieri, T.; Munn, S.; Nepelska, M.; et al. Adverse outcome pathway (AOP) development I: Strategies and principles. Toxicol. Sci. 2014, 142, 312-320. [CrossRef] [PubMed]

148. Stahl, C.H. Out of the Land of Oz: The importance of tackling wicked environmental problems without Taming them. Environ. Syst. Decis. 2014, 34, 473-477. [CrossRef]

149. Linkov, I.; Anklam, E.; Collier, Z.A.; DiMase, D.; Renn, O. Risk-based standards: Integrating top-down and bottom-up approaches. Environ. Syst. Decis. 2014, 34, 134-137. [CrossRef]

150. De Fur, P.L.; Evans, G.W.; Hubal, E.A.C.; Kyle, A.D.; Morello-Frosch, R.A.; Williams, D.R. Vulnerability as a function of individual and group resources in cumulative risk assessment. Environ. Health Perspect. 2007, 115, 817-824. [CrossRef] [PubMed]

151. Tan, Y.-M.; Clewell, H.; Campbell, J.; Andersen, M. Evaluating pharmacokinetic and pharmacodynamic interactions with computational models in supporting cumulative risk assessment. Int. J. Environ. Res. Public Health 2011, 8, 1613-1630. [CrossRef] [PubMed] 
152. Levy, J.I. Is epidemiology the key to cumulative risk assessment? Risk Anal. 2008, 28, 1507-1513. [CrossRef] [PubMed]

153. Zou, X.; Zhou, X.; Lin, Z.; Deng, Z.; Yin, D. A docking-based receptor library of antibiotics and its novel application in predicting chronic mixture toxicity for environmental risk assessment. Environ. Monit. Assess. 2012, 185, 4513-4527. [CrossRef] [PubMed]

C 2017 by the authors. Licensee MDPI, Basel, Switzerland. This article is an open access article distributed under the terms and conditions of the Creative Commons Attribution (CC BY) license (http:/ / creativecommons.org/licenses/by/4.0/). 